\title{
Gündelik Hayatı Yerinden Etmek: Türkiye'den İngiltere'ye Göç Eden Nitelikli İşgücünün Göç Etme Nedenleri
}

\author{
Özlem Avcı Aksoy* \\ Uşak Üniversitesi
}

\section{Öz}

Bu çalışma Türkiye'de eğitim almış ve iyi bir yaşam seviyesine sahip olan (ekonomik, kültürel ve sosyal olarak) nitelikli işgücünün bu yaşamlarından vazgeçerek neden göç etme düşüncesi ve davranışı içinde olduklarını anlamak ve açılamak amacındadır. Kişilerin bireysel olarak göç etme kararlarını etkileyen gündelik yaşam içinde mikro etkenler üzerinde yoğunlaşırken, çoğulculuğu ve tekilliği görmezden gelen bir gündelik hayatın eleştirel noktalarını ortaya koyma çabasındandır. Dolayısıyla ortaya çıkan göç hareketliliği, ait olduğu toplum yapısına ve iktidar ilişkilerine dair bir eleştiriyi içinde barındırır. Bu çalışma toplumsal değişim düşüncesinin gündelik hayatın içinden çıktığı ve bu değişimi gerçekleştirecek davranışların mikro politik bir direnişe dayandığı iddiasıyla hareket eder. Yapılan derinlemesine görüşmelerle bu iddia doğrulanma çabasındadır. Böylece gündelik hayat, deneyim, tekillik, arzu, kaçış çizgileri, akış kavramları üzerine odaklanarak bu kavramlarla birlikte "yerinden olma" hali kavramsal ve teorik olarak kurgulamaya çalışılmış ve kurgu çerçevesinde de yapılan derinlemesine görüşmelerle göç düşüncesi ve davranıșı, gündelik hayatın içinde ortaya çıkmış mikro politik bir eylem ve tekilliğin direnişi olarak ortaya konulmaya çalışılmıştır.

\section{Anahtar Kelimeler}

göç, gündelik hayat, tekillik, deneyim, mikro-politika

\section{Displacement of Everyday Life: Reasons for Migration of Qualified Workforce who Emigrated from Turkey to UK}

\begin{abstract}
In recent years, the qualified workforce that has received training in Turkey and has a good life (as economic, cultural, social), giving up their lives, is in the thought and behaviour of migration. This study attempts to understand and explain this immigra-

* Dr. Öğr. Üyesi, Uşak Üniversitesi, Fen Edebiyat Fakültesi, Sosyoloji Bölümü,


tion thought and behaviour of qualified workforce. On the one hand, it focuses on micro-factors in everyday life that affect people's individual migration decisions; on the other hand, it is an attempt to reveal critical points of an everyday life that ignores pluralism and singularity. Certainly, the critique of everyday life includes a critical perspective that shows the relations of power. Hence the resulting migration mobility, it contains a critique of the power relations in the social structure to which it belongs. This study acts with the claim that the idea of social change emerges in daily life and that the behaviours to realize this change are based on micro-political resistance. This claim is in an effort to confirm in-depth interviews. Thus, the concepts of daily life, experience, singularity, desire, escape lines and flow are focused on; with these concepts, displacement was conceptually and theoretically constructed; and in-depth interviews conducted within the framework of this fiction has been tried to explain the thought and behaviour of migration as a micro-political act that emerged in daily life and the resistance of singularity.

\section{Keywords}

migration, everyday life, singularity, experience, micro-politics

\section{Extended Abstract}

This study generally focuses to stereotypes that affect the life, habits and environment of the individual in everyday life and the nomadic ways of understanding created by their oppressive and controlling effects on the individual. This nomadic understanding is first of all criticized for protecting the singularity of the individual and changing the social life (as the focal points of power suppressing individual life at micro and macro levels) outside his own. When a person cannot interfere with everyday life, he decides to change the social space in which he lives. So, he displaces his own daily life. This displacement causes a nomadic mobility caused by nomadic thought. This mobility is mobility that other lives are possible.

This study is about why and how such mobility emerges around people's own experiences, and what expectations are in general, and focuses on singularities, micro-lifestyles, nomadic thoughts and lifestyles. The purpose of this study is a little different from all migration studies conducted so far, it deals with the behaviour, attitudes and perceptions of individuals in the context of inquiries in daily life and tries to interpret them as a form of micro-political action and resistance. Therefore, this study aims to discuss the motivation of immigration, despite the mainstream migration policies, based on criticism of one's own everyday life and focusing on "displacement" with the expectation of changing it.

The idea of migration and displacement is for liberation, getting rid of its roots, revealing its existence as a subject, and re-establishing itself as an individual. This escape is actually an escape that has been involved in a "subjectivation" process and is directed towards new searches. 
It is possible by escaping from all moral and political codes, overcoming the power and knowledge focuses, and becoming involved in the process of realizing its existence as an individual. Thus, as a "subject", one can act for own transformation of existence, realizing new life possibilities and the possibility of other lives.

\section{Method}

In this study, trying to explain migration thought and mobility with philosophical foundations and the concepts put forward by these foundations does not divert them from the social field, on the contrary, this method places it in the middle of his social space. For this reason, the study which is designed by feeding from the philosophical field, is discussed vertically in the conceptual framework with nomadic thought, everyday life, experience, desire, formation, molar and molecular structures, forms of power and resistance; horizontally, while discussing the causes, migration process and outcomes of this migration mobility, the theories of conflict and social systems, centre-periphery (dependency) theories, network systems theories make the site meaningful and easy to read.

The main focus of this study is to try to understand how the idea of immigration and the idea of migration emerged from the attitude of the individual, questioning and criticizing as a subject, in her vital experience. This starting point made people feel uneasy, desperate and unhappy about the future, even if they were not exposed directly, caused them to look for escape routes and caused them to change their lives when they found a little opportunity. Within the scope of the study, people who have the idea and immigration to migrate due to the difficulties, restrictions and impossibilities they face directly or indirectly in their daily lives have formed the sample of the study. Especially for similar reasons, in-depth interviews were made with people who living in Turkey and who are thinking to immigrate; and for similar reasons people who immigrate to England; the moving element of this expectation and of the desire to escape in everyday life were analysed. In-depth interviews were made with 20 people who immigrated to England and still living in Turkey and have been unable to migrate (and could not find the courage) to 10 people. These people, who have similar characteristics such as education, lifestyle, cities, etc., their way of thinking and social views are also very similar. The most obvious and common characteristics of these interviewers, that they have a good social position and economic situation in Turkey. Considering the motivations of these interviewees to immigrate, this migration mobility has been tried understood and explained with SWOT analysis method, besides repulsive and attractive reasons that caused migration. In addition, it has been added as an additional explanatory element of the study by adding it in cases that arise outside of these. 


\section{Results}

Based on the interviews, the factors are brought together that affect and direct the decisions of the people after immigration and during the decision to migrate. According to the results of the analysis, it was seen that the strengths and opportunities were expressed more. This situation seems to cause people in the thought of immigration to be more courageous and determined. Moreover, despite the difficulties experienced after migration, his statements that migration is a good decision support this situation.

According to the in-depth interview contents, the strongest part of the thought of immigration, the focal points of power which suppress everyday life and destroy singularities in the society in which the individual lives, appears to be highlighted. The focal points power mentioned here, are the strong habits and rules that are strongly felt and taken place in daily life. These are points power are the unconsciously narrowing or even destroying the area of freedom. These micro focuses of power are powered by macro power mechanisms; it increases the pressure on the individual and turns the individual into an instrumental object. Therefore, the strongest side that causes immigration is the matter of suppressing everyday life. At the beginning of the things that cause people to be unstable in the thought and mobility of immigration, It is seen that there are strong ties with the society. Especially family (mother, father, relatives), friendships and longing for homeland (nostalgia).

Looking at the society and social values that a person lives from a different society and values system causes it to question this social structure and values. This provides an opportunity to understand how possible different worlds and lives are. This study which tries to understand the migration process that starts with the person's nomadic thought and desire for change, it tried to reveal how and why people have criticized themselves and the social structures to which they belong, who have seen and experienced other countries and lifestyle. As a result, this criticism focuses primarily on the focus of power that suppresses everyday life and simulates their differences.

When we look at the similar studies conducted recently, unlike their definition of regular migration, asylum seeking and refugee and brain drain there is a social segment that questioning everyday life and acting with the perception of another possible life. Maybe, this section whose is the numerically less and the reasons are more incomprehensible, appears to be in migration mobility as a form of resistance based on the rejection of an authoritarian everyday life.

This sample is actually the beginning of a process that affects the entire social structure; it presents a new form of immigration and immigrants with a look other than immigration typologies. It is an undefined social category that is conscious, questioning, confronting the purpose of self-realization, not ignoring the environmental factor, acting with a solidarity approach that destroys hierarchies and desiring a liveable life. 


\section{Giriş}

Toplumsal bir olguyu anlamak ve açıklayabilmek, öncelikle bu olgunun kavramlarla olan ilişkisini anlamaya ve toplumsal gerçeklikteki karşılı̆̆ı ile ilişkilendirmeye dayanır. Daha önce yapılan çalışmaları bir çıkış noktası olarak alıp, sonrasında kendine özgü sorgulama ve değerlendirmelerle bir adım ileri götürüp açıklamaya çalışmak, olguların zamansal, coğrafi ve nedensel farklılıklarına göre anlaşılabilir kılınmasını sağlar. Elbette bir olguyu tek başına neden ve sonuçlarla açıklamak, kendi pratiği çerçevesinde sorgulamak yetersiz ve açıklayıcı olmaktan öte sadece betimleyen bir çabaya dönüşebilir. Bu nedenle her olgu, mutlaka diğer olgularla ilişkisel bir biçimde ele alınması, sorgulanması ve açılanması gerekir.

Değişen sosyo-ekonomik, coğrafi ve siyasi koşullar (özellikle gittikçe otoriter bir hal alan siyasi yapılar), bilgi ve iletişim sistemleri her şeyden önce göç olgusunu ve toplumsal bir hareketlilik (social mobility) olarak insanların göç algısını, motivasyonunu ve pratiğini de değiştirmiștir. Göç hareketliliğinin, farklı nedenler sonucunda farklı görünüm ve biçimlerle ortaya çıktığı görülür. Göçe neden olan unsurların siyasal, ekonomik, toplumsal birçok odak noktası vardır: Ekonomik krizler, siyasal değişimler ve otoriter yönetimler, savaşlar, doğal afetler vs. Bu nedenler, kitlesel ya da bireysel olarak insanların göç etme motivasyonlarını harekete geçiren temel unsurlardır.

Bu çalışma genel olarak, gündelik hayatın içinde bireyin yaşamını, alışkanlıklarını ve içinde yaşadığı çevreyi etkileyen kalıpların ve bunların birey üzerindeki baskıcl, kontrol edici etkilerinin kişide yarattığı göçebe anlayış biçimlerine odaklanır. Bu göçebe anlayış her şeyden önce bireyin tekilliğini koruma ve kendi dişındaki toplumsal yaşama (mikro ve makro seviyelerde bireysel yaşamı baskılayan iktidar odakları olarak) dair bir eleştiridir ve her şeyden önce gündelik yaşamı değiştirmeye yönelik bir içeriğe sahiptir. Kişi gündelik hayata müdahale edemediğinde (ki bu durum iktidar odaklarının ne kadar köklü ve güçlü olduğunu gösterir), onu değiştiremediğinde ait olduğu toplumsal yapıyı değiştirme kararı alır. Yani gündelik hayatını yerinden eder. Bu yerinden olma hali ise göçebe düşüncenin neden olduğu göçebe bir hareketliliğe neden olur. Bu hareketlilik, başka yaşamların da mümkün olduğuna dair bir hareketliliktir. Bu çalışma, böylesine bir hareketliliğin, kişilerin kendi deneyimleri etrafında neden ve nasıl ortaya çıktığına ve genel olarak beklentilerin ne olduğu üzerinedir ve tekilliklere, mikro hayat tarzlarına, göçebe düşünce ve yaşam biçimlerine odaklanır. 


\section{Araştırmanın Güzergahı}

\section{Kurguya Dair: Amaç, Konu, Kapsam}

$\mathrm{Bu}$ çalışmanın amacı şimdiye kadar yapılan tüm göç çalışmalarından biraz farklı olarak, bireylerin göç etme davranış, tavır ve algılarını gündelik hayat içindeki sorgulamalar bağlamında ele almakta, mikro politik bir eylem ve direnme biçimi olarak yorumlamaya çalışmaktadır. Dolayısıyla bu çalışma, ana akım göç politikalarına karşın, kişinin kendi gündelik hayatına dair eleştirilere dayanan ve onu değiştirme beklentisiyle "yerinden olma" durumuna odaklanarak, göç etme motivasyonunu tartışmayı amaçlar. Göç ve yerinden olma1 fikri özgürleşmeye, köklerinden kurtulmaya, özne olarak varlığını ortaya koymaya ve bir birey olarak kendini yeniden kurmaya içkindir. Bu kaçış aslında bir "özneleşme" sürecine dâhil olmuş ve yeni arayışlara yönelmiş bir kaçıştır. Kişinin tüm ahlaki ve siyasi kodlardan kaçarak, iktidar ve bilgi odaklarını aşarak özneleşmesi ve birey olarak varlığını gerçekleştirme sürecine dâhil olmasıyla mümkün olur. Böylece "özne” olarak kişi, yeni yaşam olanaklarını ve başka hayatların imkânını fark edip ve kendi varoluş dönüşümü için harekete geçebilir.

Bu çalışma kapsamında insanların bireysel olarak - bilinçli bir özne formunda - gündelik hayatlarındaki temel beklentilerinin, kaygılarının, sıkıntılarının, mutsuzluklarının, güvensizlerinin, umutsuzluklarının nasıl göç fikrinin oluşmasına neden olduğu sorusu tartışılacaktır. Özellikle kendi ülkesinde oldukça rahat bir sosyo-ekonomik konuma sahip olan insanların, bu konumlarının ve yaşam standartlarının yitirilmesi pahasına hangi neden ve beklentilerle göç ettikleri sorusu üzerine odaklanılmıştır: İyi bir işiniz, eviniz, aile yaşantınız var, daha ne istiyorsunuz! Peki, neden buralardan gitmek istiyorsunuz? Hem de işsiz kalma, sahip olduğunuz yașam konforunuzu kaybetme ya da bu konfordan uzunca bir süre uzak kalma pahasına... Böyle bir sorgulamanın cevabına dair izler Maffesoli'nin "İnisiyatik Göçebelik" adlı çalışmasında sürülebilir:

... göçebelik sadece ekonomik ihtiyaç ya da salt işlevsellik tarafından belirlenmez. Harekete yol açan sebep tamamen başkadır: kaçma arzusu. Bu yer, alışkanlık, ortak değiștirmeye teșvik eden bir çeșit "göçmenlik itkisi"dir ve bu kişiliğin yüzlerinin çeşitliliğini gerçekleştirmek içindir Dışarıyla, tuhaf ve yabancı olanla çatışma, Ortaçağ bireyinin her bir kişide uykuya yatmış yapısal çokluğunu yaşamasına müsaade eden şeydir. Böylesi bir göçebelik elbette tüm bir nüfusun işi değildir, fakat kimileri tarafından, paroksitik bir şekilde yaşanmakta ve global bir kolektif imgelemi beslemektedir. Bu haliyle toplumun bütününün müdahil olduğu bir durumdur (2014: 60).

Dolayısıyla bu sorgulamanın cevabını gündelik hayatın içinde kaybolan tekillikler ve bu tekilliklerin hayata tutunma taktikleri ve direnme biçimleri içinde aramak gerekir. Buna göre göçebeliği tanımlayan en önemli şey tekilliklerdir.

1 "Yerinden olma” fikri, "yerinden edilme" fikrinin aksine gönüllüğü ifade eden bir ifadedir. 
Yani göçebeleri göçebe yapan fiziksel hareketlilikleri veya hareketsizlikleri değil tekillikleridir. Molar kümelerden kopan, yaratıcı oluş deneyimleridir. Kaçış çizgilerinin yarattığı minör politika, bir sınıfı veya azınlık kimliğini temsil etmek değil, kaçış çizgilerine bağlanma süreci, dolayısıyla bir değişim sürecidir. Hardt ve Negri'ye göre değişimi (devrimi), bütün çelişkilerin çözüleceği radikal bir "olay" anı olarak görmek yerine bir süreç olarak başlatmaktır. Çekilme ve eksilme yoluyla iktidar alanlarını boşaltmak, "toplu çıkış" çağrısıdır. Bu bağlamda toplu çıkış genellikle sabotaj, işbirliğinden çekilme, karşı-kültürel pratikler ve genelleştirilmiş itaatsizlikler biçimini alır. Böylesi pratikler etkilidir; çünkü biyo-iktidar daima, üzerinde hüküm sürdüğü öznelliklere tabidir. Onlar alanı tahliye ettiklerinde, biyo-iktidarın katlanamadığı boşluklar yaratırlar" (Negri\&Hardt, 2011, s.359). Mikro politik bir eylem ve bir direnme olarak arayış beklentisi içinde olan kaçış biçimleri olarak bu göç hareketliliği, kendi tekilliğinin karşılık bulamadığı ve bu noktada herhangi bir değişimin sağlanamadığı toplumsal yapı içinde bir boşluk yaratır. Bu boşluklar ise Negri ve Hardt'ın söylediği gibi iktidarı tedirgin eden ve şimdi ve gelecekteki kendi varoluşunu tehdit eden boşluklardır. Nitelikli iş gücünün göç hareketliliği ile yarattıkları boşluklar, iktidar yapıları içinde iktidara karşı geliştirdikleri büyük bir eleştiriyi içinde barındırır. Belki de bu eleştiri, iktidarın dönüşümünü gerçekleştirebilecek bir direnme biçimi olarak görülebilir.

Son 10 yılda ülkemizden özellikle batı ülkelerine, başta ABD ve Avrupa ülkelerine doğru (özellikle Almanya ve İngiltere olmak üzere) yoğun bir göç hareketliliği gerçekleşmektedir². Daha gelişmiş bir ülkeye doğru göç hareketliliği genel olarak dünya sistemleri teorisi çerçevesinde tartışılan bir olgudur. İnsanların daha iyi bir yaşama ve sosyo-ekonomik koşullara ulaşmak için göç ettikleri görülür. Bu tartışmasız göç hareketliliğinin en temel rasyonalitesidir. Son dönemlerde yaşanan bu göç hareketliliğin nedenleri, biçimi ve amacı daha önceki göç hareketliliğinden (örneğin 1950’lerdeki işçi göçü ya da 1980 sonrası yaşanan siyasi göçlerden) farklı olarak belirginleşmektedir. Bu nedenlerin başında ülke içinde yaşanan siyasal baskıların (özellikle 15 Temmuz Darbe hareketi sonrasında yaşanan OHAL süreci, Barış Akademisyenlerinin yargılanmaları ve tüm bu süreçte yaşanan haksız yargılanmalar, tutuklanmalar, artan siyasi baskılar vb) ekonomik istikrasızlığın, toplumun bir çok kurumda karşımıza çıkan ayrımcılığın gittikçe artması, bu durumların normalleşmesi ve tüm bu makro etkilerin gündelik hayatı da etkileyen daha mikro boyutları sıralanabilir. Çünkü gündelik hayatın beslendiği yapı hakim olan üst siyasi yapılardır. Bu üst siyasi yapılar, gündelik hayatın kontrol eden, baskılayan mikro iktidar odaklarını daha belirgin ve hissedilir hale getirir. Makro boyuttaki etkilerden bağımsız olarak düşünülemeyen fakat gündelik hayat için-

2 Bu konudaki yıllara, alanlara ve ülkelere göre değişen rakamlara ulaşmak için kişilerin kendi deneyimleri doğrultusunda serbest olarak oluşturulan bir veri kaynağı olarak ortaya çıkan Büyük Göç çalışmasına bakılabilir: https://buyukgoc.github.io/index.html [10.11.2019] Ayrıca benzer bir biçimde bu göç hareketliliğine dair sayısal verilere TUiKK raporlarından ve Göç İdaresi'nin güncel resmi rakamlarından da ulaşılabilir. 
de doğrudan bir etkiye sahip olan mikro unsurlar bu çalışma açısından daha dikkat çekicidir. Örneğin makro olarak ekonomik yapıda kalkınmanın öncü sektörü olarak inşaat sektörünün kent alanlarında hakim etkisi ve tüm yaşam alanlarını dönüştürmesi, insanların gündelik yaşam alanlarının kısıtlanması yönündeki önemli eleştirilerin başında gelir. Toplumun genelinde kadına ilişkin şiddet ve ayrımcılığın artması, aile içinde toplumsal cinsiyete dayanan ayrımcılığın ve baskının daha da artmasına neden olduğu görülür.

Bu çalışma kapsamında sorgulanan iktidar meselesi, makro iktidar alanlarının da etkisiyle etkisi gittikçe daha fazla belirginleşen gündelik hayat içindeki etkin ve davranışsal alanlarını belirleyen ve etkileyen mikro iktidar alanları/ odaklarının sorgulanmasına dayanır. Elbette siyasi, toplumsal ve ekonomik alanda yaşanan tüm istikrarsızlıklar, baskılar ve ayrımcılık doğrudan ve dolaylı olarak insanların gündelik hayatına yansımakta ve kişinin yaşamında huzursuzluğa, tedirginliğe, kaygıya ve içinde yaşadığı topluma karşı bir güvensizliğe neden olur. Gündelik hayattaki bu huzursuzluk ve tedirginlik hali ise insanların, mümkün olan yeni yaşam alanları arayışına yönlendirmektedir. Elbette bu yöneliş bireyin kendi yaşamsal deneyimleri ile biçimlenen ve bireyi harekete geçiren bir durumdur. Bireyin kendi farklılığı, tekilliğidir. $\mathrm{Bu}$ farklılık, yerinden olma hareketliliğini sağlar / akışını hareketlendirir.

\section{Sahaya Dair}

\section{Hipotezler, Yöntem ve Teknikler}

İçinde bulunduğumuz dönem, sınırların kalktığı, bireylerin ve toplumların biçimsel ve kültürel olarak birbirine benzediği, gündelik yaşamların da küreleşmenin bir tarafında olduğu ve yaşam biçimlerinin de dönüştüğü bir dönemdir. Özellikle bilgi ve iletişim teknolojileri ile birlikte bireyin gündelik hayatını dönüştüren ve başka yaşamları arayış imkânını ortaya koyan bir özelliğe sahiptir. Dolayısıyla değişen dünyanın doğrudan etkisi makro ölçüde toplumsal yapılar üzerine olmasının ötesinde doğrudan bireyin gündelik yaşamı, alışkanlıkları ve beklentileri üzerinedir. Günümüz bireyi içinde bulunduğu koşulları kolaylıkla farklı olanla karşılaştırma, eleştirmekte ve beklentilerini net bir biçimde ortaya koyabilmektedir. Karşılaştırma, eleştirme ve beklentiler, içinde yaşadığı koşullara dairdir. Bireyin farklı olanla karşılaşması, ona içinde bulunduğu koşulları tanımlayabilme yetisini kazandırır. Bu tanımlama biçimi ise farklı olanı talep etme, var olanı değiștirme içkinliğine sahiptir. Böylesine toplumlarla iç içe geçme hali ise insanlarda yeni beklentiler yaratmakta ve bireysel olarak beklentisini karşılayan yerlere doğru (imkânlar doğrultusunda ve hatta imkânlarını yaratılması doğrultusunda) bir hareketliliğe neden olmaktadır. Bu nedenle ve yaşanan etkileşimler sonucunda günümüzde etkin olan önemli bir toplumsal olgu olarak göç olgusunun ortaya çıktığı görülür.

Bu çalışmada göç düşünce ve hareketliliğini felsefi temellerle ve bu temellerin ortaya koyduğu kavramlarla açıklanmaya çalışılması, toplumsal alandan 
uzaklaştırmamakta aksine toplumsal alanına tam ortasına oturmaktadır. $\mathrm{Bu}$ nedenle felsefi alandan beslenerek kurgulanan çalışma dikey olarak göçebe düşünce, gündelik hayat, deneyim, arzu, oluş, molar ve moleküler yapılar, iktidar ve direnme biçimleri ile kavramsal çerçevede tartışılırken yatay bir biçimde ise bu göç hareketliliğin nedenleri, göç süreci ve sonuçlarını tartışırken belirgin bir biçimde çatışma ve sosyal sistemleri teorileri, merkez-çevre (bağımlılık) teorileri, ağ sistemleri teorileri sahanın okunmasını anlamlı hale getirmekte, kolaylaştırmaktadır.

Bireyin bir özne olarak sorgulayan ve eleștiren tavrından, kendi yaşamsal deneyiminde hareketle göç fikrinin, göçebelik düşüncesinin nasıl ortaya çıktığını anlamaya çalışmak, bu çalışmanın ana odak noktasıdır. Bu çıkış noktası, insanların doğrudan maruz kalmasa bile geleceğe dair kendisini huzursuz, umutsuz ve mutsuz hissetmesi, kaçış yolları aramalarına neden olmuş ve az da olsa bir fırsat bulduklarında yaşamlarını değiștirmelerine neden olmuştur. Çalışma kapsamında gündelik yaşamlarında doğrudan ya da dolaylı olarak karşılaştıkları baskılar, kısıtlamalar ve imkânsızlıklar nedeniyle birçok zorluğu göze alarak göç etme düşüncesinde ve hareketliliği içinde olan kişiler, çalışmanın örneklemini oluşturmuştur. Özellikle benzer nedenlerden dolayı Türkiye'de yaşayan ve göç etmek düşüncesinde olan insanlarla ve benzer nedenler yüzünden İngiltere'ye göç3 etmiş insanlarla derinlemesine görüşmeler yapılmış ve bu beklentinin ve kaçma arzusunun gündelik yaşamdaki hareket ettirici unsurlarına bakılmıştır. Türkiye'de olan ve hala tam olarak gitme fırsatı (ve cesareti) bulamamış 10 kişi ile ve ne olursa olsun "gemileri yakmayı başarmış" 20 kişi ile görüşme firsatı bulunmuştur. Eğitim, yaşam tarzı, yaşanılan kentler gibi benzer özelliklere sahip olan bu kişilerin yaşama ve ait oldukları topluma bakışları da oldukça birbirine benzerdir. Bu görüşmecilerin en belirgin ve ortak özellikleri Türkiye'de iyi bir sosyal konuma ve ekonomik duruma sahip olmalarıdır. Görüşmecilerin tamamı üniversite mezunudur ve eğitim aldıkları alan ile ilgili olarak Türkiye'de özel ve kamu sektörlerinde belli süre çalıştıktan sonra göç etmeye / yerinden olmaya karar vermiş kişilerdir4. Bu görüşmecilerin göç etme motivasyonları göz önünde bulundurulduğunda göçe neden olan itici ve çekici nedenlerin yanı sıra bu göç hareketliliğinin firsatları, engelleri, tehditleri ve güçlükleri SWOT 5 analiz yöntemi ile

3 Bu veriler, 2019 yılında post doktora çalışması için İngiltere'de bulunduğum süre içinde benzer nedenler üzerine göç etmiş olan insanların (Londra, Oxford, Liverpool, Mancester'da yaşayan) bu göç etme davranışı üzerine belli aralıklarla yapılmış olan derinlemesine görüşmelere dayanmaktadır.

4 Bu konuda daha ayrıntılı bilgi için makale sonundaki görüşmecilere dair demografik tabloya bakınız.

5 SWOT analizi 1960 'lı yıllarda Albert S. Humprey tarafından kullanılmaya başlanmıştır. Daha çok kurumsal yapılar içinde yönetsel ilişkilerin analizinde kullanılan bir yöntem olmasının yanı sıra göçe dair neden ve sonuçları ortaya koyabilme kapasitesi nedeniyle göç çalışmalarında da anlamlı bir analiz yöntemi olarak değerlendirilebilir. Bu çalışma kapsamında göç hareketliliğindeki etkilerin göçmenler açısından güçlü yönler (Strengths), zayıf yönler (Weaknesses), firsatlar (Opportunities) ve tehditler (Threats) üzerine odaklanır. 
anlaşılmaya ve açıklanmaya çalışılmıştır. Ayrıca bunların dışında ortaya çıkan durumlarda eklenerek çalışmanın ek bir açıklayıcı unsuru olarak ortaya konulmuştur.

$\mathrm{Bu}$ çalışmada saha verileri değerlendirilirken özellikle göç hareketliliğine neden olan ve göç motivasyonunu belirleyen ve etkileyen unsurlar üzerine odaklanılmış ve bu odaklar ise göç teorileri etrafında karma bir yapı ortaya koyulmuştur. Ağ teorisinden kesişen firsatlara merkez-çevre etkisinden itme ve çekme teorisine kadar tartışılan teoriler belli başlı vurguladıkları konularla saha verilerini açıklayan bir içeriğe sahiptir. Bu teorilerin sunduğu açıklamalar öngörüsünde saha verileri yorumlayıcı bir bakışla açıklanmış ve sonrasında SWOT analizini kullanılarak değerlendirilmiştir. Burada SWOT analizini uygularken kişinin gündelik hayatı ve çalışma hayatı üzerinden iki farklı değerlendirme biçimine tabi olmak esastır. Çünkü gündelik hayata ve çalışma hayatına dair beklentiler ve zorluklar değişkenlik göstermektedir. Gündelik hayat daha çok özgürlük imkânları sunarken, çalışma hayatı (yabancı ya da göçmen olma durumundan dolayı) daha zorlu ve belki de baskıcı koşullara sahip olabilmektedir.

Gündelik yaşamları üzerinden beklentilere sahip olan bu kişilerin kaçma düşüncesinin temelinde, ait oldukları topluma dair bir değişimi sağlayamama ve artık bu değişimin gerçekleşeceği fikrine inanmama düşüncesi vardır. Bu düşünce onları arayışa sokmuş ve kaçış olarak değerlendirdikleri göç hareketliliğine neden olmuştur. Başka bir yaşamın mümkün olduğuna inanan bu kişiler, kendi ait oldukları coğrafyada bunu sağlayamamış ve sahip oldukları her şeyi terk ederek mümkün olan başka yaşamı başka ülkelerde arama çabasına girmişlerdir. Bu arayışın ortaya çıkması, yaşamın sorgulanması ve kendi tekilliğinin fark edilmesine dayanır. Böylece göçebe düşüncenin oraya çıkışı;

- $\quad$ Insanların kendi gündelik hayatlarına dair farkındalıkları ve beklentileri değişmektedir.

- $\quad$ Bu farkındalıklar ve beklentiler kişilerin eğitimleri ve sahip oldukları kültürel sermaye ile doğru orantılıdır. Kültürel sermayeye sahip olmak ise ekonomik sermayeyi gerektirir.

- $\quad B u$ beklentiler yaşadıkları toplum içinde gerilimlere, çatışmalar neden olmakta ve bu durum ise kişiyi gündelik hayat içinde baskılamaktadır.

- $\quad$ Kişinin daha önce yurtdışında (özellikle gelişmiş batı ülkelerinde tatil, eğitim gibi nedenler uzun ya da kısa süreliğine bulunmuş olması) göç fikrinin oluşmasında önemli bir etkiye sahiptir.

- $\quad$ Göçebe düşüncenin sağladığı farkındalık, gündelik hayatın sorgulanmasına ve değişim talebine neden olur. Böylece düşünce harekete dönüşür.

- $\quad$ Bu göçebe hareket hali ise imkânlar (ekonomik, eğitim, dil yeterliliği gibi) çerçevesinde gerçekleșebilmektedir. 
Göç sürecindeki önemli aşamalardan biri hedef ülkeye ulaşıldı̆ğında yaşanan (yaşanacak olan) entegrasyon sürecidir. Bu sürecin istenilen bir biçimde sürdürülmesi, hedef ülkedeki yakınlıkların / bağların varlığıdır.

Niteliksel veri toplama tekniklerinin (derinlemesine görüşmeler, vaka analizi) kullanıldığı bu çalışmada, TUIKK, Göç İdaresi ve Büyük Göç hareketliliği çalışmalarının sayısal verileri de (ikincil veri kullanımı) göz önünde bulundurulmuştur. Bu sayısal verilerden faydalanırken özellikle Büyük Göç çalışmasının verileri odak olarak alınmıştır. Çünkü burada kişiler kendi istekleri ve yaşadıkları deneyimler doğrultusunda veri girişi yapmaktadır. Veriler anlık olarak girilmektedir ve bu nedenle güncel ve aktiftir. Büyük Göç çalışmasında, 1995'den bugüne kadar aktif göç hareketliliği yıllar, meslekler ve ülkeler bazında görülebilir. Buna göre nitelikli iş gücünün yoğun olarak en fazla göç ettiği ülkeler sırasıyla ABD, Almanya, İngiltere, Hollanda ve Kanada'dır. Verilerin başlangıç yılı olarak alınan 1995 yılına ait veri olmamasına karşın önemli ölçüde veri girişi 2010 yılından sonra başladığı, 2015 sonrası ise hızlı bir biçimde arttığı görülür. Toplamda ise $1750^{6}$ kişinin bu göç haraketliliği içinde kendilerine ait verileri paylaştığı görülür. Ayrıca aktif olarak veri kaydı girişi de devam etmektedir. En fazla göç veren sektörler bilgi ve iletişim teknolojileri, mühendislik ve akademidir. Öğrenci olarak gidenlerin sayısı da oldukça yüksektir. Bu süre içinde ABD'ye toplam 335 kişi göç etmiş̧tir. Bu kişilerin 101'i İletişim Teknolojileri, 48'i mühendislik, 40'ı Akademi'den, 21'i ise sanat alanındandır. Almanya'ya göç edenlerin sayısı ise 313'dür. Bu kişilerin 124'ü Bilgi Teknolojileri, 47'si Mühendislik, 25'i Akademi alanında çalışmaktadır. Bu sayılara da 18 öğrenci eklenmiştir. Yoğun olarak göçün yaşandığı üçüncü ülke ise İngiltere'dir. Bu süre içinde İngiltere'ye nitelikli iş gücüne sahip 230 kişi göç etmiştir. Bu göç hareketliliği içinde olan kişilerden, (göç etmeden önce Türkiye'de çalıştığı uzmanlık alanları) 83 kişi Bilgi Teknolojileri, 23 kişi tasarım, 17 kişi akademide, 16 kişi de mühendislik alanında çalışmaktadır. Ayrıca İngiltere'deki sayıya 26 kişi de ayrı olarak İrlanda olarak eklenmiştir. Elbette bu rakamlar yüksek görülmemekle birlikte, bu çalışma az da olsa bir göç hareketliliğinin nedenlerini sorgulamaya ve anlamaya çalışma çabasında olduğundan dolayı, bu sayısal verilere dikkat edilmiștir. Zira burada sayılardan öte nitel veriler daha çok dikkat çekmektedir. Dolayısıyla bu sayısal verileri nitel verilerle doğrulayan benzer çalışmalar da son dönemde dikkat çekicidir. 140 journos çalışma grubunun hazırlamış olduğu "Seküler Göç" çalışması bu konuda oldukça dikkat çekicidir. Ayrıca Gözde Kazaz ve İlksen Mavituna'nın (2018) “Bu ülkeden Gitmek", Bahar Çuhadar'ın (2019) “Yeni Ülke Yeni Hayat”, Gökhan Kutluer'in (2019) “Türkiye'den Gitmek: İtalya'ya Uzanan Bir Göç Hikayesi” adlı kitapları bu çalışmalardan bazılarıdır. Bu çalışmalar kendi gündelik hayatlarındaki baskıcı (bu baskıcı anlayışı gündelik hayatın içine yerleșen ve bireyin tekilliğini gölgede bırakan/görünmez kılan yazısız

6 Bu çalışmaya harita ve diyagram üzerinden verilere ulaşılabilir ayrıca tüm verilerin sıralandığı bir excel dosyası da mevcuttur. https://buyukgoc.github.io/index.html [10.11.2019] 
kurallar bütünü olarak düşünmek gerekir) ve aynılaşan hayat tarzlarına karşı bir eleştiri olarak ortaya çıkan göç etme motivasyonlarını içeren göç deneyimlerinin paylaşılmasına dayanır.

\section{Bulgulara Dair}

Göç tartışmalarındaki farklı eleştiri biçimlerini anlamak için, insanların göç fikrini ve davranışını nasıl meşrulaştırıp, kendileri için nasıl bir gerekçe ile gerçekleştirdiklerini anlamaya çalışmak hem deneysel bir çabaya hem de teorik bir yol haritasını gerektirir. Tüm kavramsal ve teorik tartışmalar, saha görünümleri uluslararası bir göç hareketliliğin çok kolay verilen kararlar olmadığını, beklentiler kadar korkuları da beraberinde getiren zor bir karar ver(e)me(me) süreci olduğunu gösteriyor. Yapılan görüşme içeriklerine göre yapılan SWOT analizinde Güçlü ve Zayıf yönler kaynak kişinin içinde bulunduğu karar verme sürecine dair durumu ifade ederken Firsatlar ve Tehditler ise kendi ülkesine ve hedef ülkeye dair durumları ifade eder.

SWOT analizinde güçlü ve zayıf yönler içsel yani göç etmiş ya da göç etme düşüncesinde olan kişilerin kendilerinden kaynaklanan yönlerini ortaya koyarken, firsatlar ve tehditler ise dışsal yani göç edilen ya da edilmek istenen ülkeden kaynaklanan özellikleri ortaya koyar. Bu analiz, göç etmiş olan ya da göç etme düşüncesinde olan kişilerin göç etme kararlarında kendilerinden kaynaklanan güçlü zayıf yönlerini ve göç ettikleri yerde elde ettikleri firsatları ve baş etmek zorunda kaldıkları sorunları gösteriyor. 
Tablo 1. Göç Etme Hareketliliğine Dair Bir Analiz Denemesi

\section{Güçlü Yönler \\ (Strenghts)}

İyi bir eğitim almış olması

Yabancı dil bilmek

Daha önce yurtdışında yașamış ya da yurt-

dışına sık sık gitmiş olması

Farklı yaşam biçimlerini ve olanaklarının farkındalığı

Ekonomik bir birikime sahip olması

Kararlılık ve ne istediğini bilmek

Farklılıkları görmek ve öğrenme merakı

Göç edilmek istenen ülkede kurulan yakın-

lıklar (sosyal sermayenin varlığı)

Kolay uyum sağlayabilme

Tek başına olmak

Aile ile birlikte gitme (eş ve çocuk)

$\mathrm{Bu}$ durum hem kişiye güç vermekte, destek sağlamakta hem de sorumluluğun getirdiği bir tedirginliğe, kaygıya neden olmaktadır)

Beklentilerin (mesleğini sürdürme, iyi bir sosyal çevre ve yaşam, ekonomik olarak güçlenme gibi) daha uzun vadede planlanması

Zorlukların farkında ve hazırlıklı olma

Geri dönebilme firsatı

\section{Firsatlar}

\section{(Opportunities)}

Beklenen ve istenen bir yaşam

İyi bir iş ve yüksek bir gelir

Eğitimini istediği seviyede sürdürebilme

Gündelik hayatın mikro iktidar odaklarından kurtulma ve daha özgür bir yașam "Yenilikler"; Yeni eğitim firsatları, yeni bir sosyal yaşam ve çevre, yeni iş firsatları, çocuklara sunulan yeni ve öncelikli imkânlar

Güvenceli ve güvenli yaşam

Çocukların daha iyi bit eğitim alabilmesi

Güçlü Sosyal Devlet

Göç edilen yerde tanıdıkların (akraba, arkadaşlar gibi) olması

Ekonomik ve kültürel sermayeye sahip olmak

\section{Zayıf Yönler \\ (Weaknesses)}

$\mathrm{Az}$ gelişmiş bir ülkede yetişmiş olması

Yurda duyulan özlem ve geride bırakılan aile ve arkadaşlıklar

Mesleği ile ilgili göç edilen ülkede bir deneyime sahip olmamak

Yabancı dilde yetersizlikler

Ekonomik birikimin yetersizliği (TĹnin değerinin düşük olması)

Korkular: Ailenin zor durumda kalma korkusu (eş ve çocuk ile birlikte göç etme durumunda); uzun süre iş bulamama; uzun vadede kendi mesleğine başlayamama

Tek başına olmak (bir taraftan karar vermeyi kolaylaştıran bir unsur iken diğer yandan yaşanan sorunlarla baş etmede yalnız olmanın zayıflığını ifade etmektedir.)

\section{Tehditler \\ (Threats)}

İș bulamama

Pahalı bir yaşam

Uyum sağlayamama

Güvencesiz (kayıt dışı) çalışmak zorunluluğu (başlangiçta)

İstediği mesleği (sonrasında da)

sürdürememe

Kültürel Dışlanma

Ekonomik sıkıntılar

Ekonomik ve siyasal Dışlanma

İstenilen / beklenildiği gibi bir çevre-

de yaşayama

Başarısız olma

Geri dönme

Yapılan görüşmelere dayanarak göç ettikten sonra ve göçe karar verme sırasında kişilerin kararlarını etkileyen ve yönlendiren unsurlar bir araya getirilmiştir. Analiz tablosuna genel olarak bakıldığında sağ sütunda yer olan güçlü yönler ve firsatlara dair ifade edilen beklentilerin, sol tarafta yer alan zayıf yönleri (göçe dair kaygıları, çekinceleri ifade eden) ve tehditleri ifade eden korkulardan daha fazla olduğu görülüyor. Bu durum ise göç etme yönünde 
kişilerin daha cesaretli ve kararlı olmalarına neden olmakta ve göç eden insanların ise yaşanan zorluklara rağmen göç etmenin yerinde bir karar olduğu yönündeki duygularını ifade ediyor.

Yapılan derinlemesine görüşme içeriklerine göre hazırlanan bu analize göre göç etme düşüncesinin en güçlü yanı yaşadığı toplumda gündelik hayatını baskılayan ve tekillikleri yok eden iktidar odaklarıdır. Burada vurgulanan iktidar odakları, gündelik hayat içinde güçlü bir biçimde hissedilen ve yer etmiş olan kalıp alışkanlıklar ve kuralların, farkında olmadan kişinin özgürlük alanını daraltması hatta yok etmesidir. Bu mikro iktidar odakları, güçlü iktidar mekanizmalarından da güç alarak birey üzerindeki baskıları arttırmakta ve bireyi araçsal bir nesne haline dönüştürmektedir. Göç hareketliliğine neden olan en güçlü yan gündelik hayatın baskınlanması meselesidir. Kişileri göç etme düşüncesi ve hareketliliğinde kararsız kılan dikkat çekici unsurların başında ise kişinin yaşadığı toplumla kurduğu güçlü bağlardır. Özellikle aile (anne, baba, akrabalıklar), dostluklar ve ülkeye dair özlem.

Kişinin içinde yaşadığı topluma ve toplumsal değerlere, farklı bir toplumdan ve değerler sisteminden bakması, içinde var olduğu toplumu ve kendi gündelik yaşamını sorgulamasına neden olmaktadır. Bu durum ise farklı dünyaların ve yaşamların ne kadar mümkün olduğunu anlama firsatı sunar. Bu çalışma kișinin göçebe düşünceye sahip olması ve değișimi arzulamasıyla başlayan göç etme sürecini anlama çabasındadır. $\mathrm{Bu}$ çaba sonucunda başka ülkeleri ve yaşam biçimlerini görmüş ve deneyimlemiş olan kişilerin kendilerini ve ait oldukları toplumsal yapıları sorgulama fırsatı vermiş ve eleştirel bir bakış geliştirmelerine neden olmuştur. Bu eleştiri öncelikle gündelik hayata ve gündelik hayatı baskılayan ve farklılarını benzeştiren iktidar odakları üzerine yoğunlaşmaktadır.

Tablo 2. Kaynak Ülke ve Hedef Ülke Karşılaștırması (Beklentilere dayanan)

\begin{tabular}{|l|l|}
\hline Kaynak Ülke & Hedef Ülke \\
\hline Çevresel koşullar ve doğanın tahribi & Çevresel koşullar ve doğal yaşam \\
\hline Plansız ve karmaşık kentsel alanlar & Planlı ve düzenli kent alanları \\
\hline Kişiler arası tahakküm ilişkisi & Hiyerarşik olmayan daha eşitlikçi ilişkiler \\
\hline Eril iktidar ve tahakküm & Cinsiyet farklılıklarının görünmezliği \\
\hline $\begin{array}{l}\text { Otoriterleșen toplumsal alan ve } \\
\text { gündelik hayat }\end{array}$ & Güçlü sosyal devlet (eğitim, sağlık gibi) \\
\hline $\begin{array}{l}\text { Çalıșma koşullarının ağırlığı (uzun } \\
\text { çalıșma saatleri) }\end{array}$ & $\begin{array}{l}\text { Çalışma koşullarının (kayıt içi) yasa } \\
\text { güvencesinde oluşu }\end{array}$ \\
\hline $\begin{array}{l}\text { Güvensizlik ve tekinsizlik (kurumlara } \\
\text { ve insanlara duyulan güvensizlik) }\end{array}$ & Güven olgusunun güçlü oluşu \\
\hline
\end{tabular}

Son dönemde yapılan benzer çalışmalara bakıldığında da düzenli göç, sığınma talebi ve mülteci olma ve beyin göçü tanımlamalarının dışında gündelik hayatı sorgulayan ve başka bir yaşam mümkün algısı ile hareket eden bir kesim 
söz konusu. Belki sayı olarak daha az ve gerekçeleri daha anlaşılmaz olan bu kesim otoriterleșen bir gündelik hayatın reddedilișine dayanan bir direnme biçimi olarak göç hareketliliği içinde olduğu görülüyor. Bu durum aslında tüm toplumsal yapıyı etkileyen bir sürecin başlangıcı olarak göç tipolojilerinin $\mathrm{d}_{\mathbf{l}}$ şında bir görünüme sahip yeni bir göç ve göçmen biçimini karşımıza çıkarmaktadır. Karşımızdaki bilinçli, sorgulayan, kendini gerçekleştirme amacının derdinde olan, çevre faktörünü göz ardı etmeyen, hiyerarşileri yıkan dayanışmacı bir yaklaşımla hareket eden ve yaşanabilir bir hayatı arzulayan, tanımlanamaz toplumsal bir kategoridir.

\section{Göç Teorilerine Dair}

\section{Kısa Bir Giriș}

Bu çalışma her ne kadar göçebe (nomadic) düşünce, özne, tekillik, mikro-politika, yerinden olma, gündelik hayatın iktidar odakları ve direnme biçimleri gibi daha felsefi temellere dayansa da üzerine sorgulama yapılan toplumsal bir hareketlilik olarak bir yerden bir yere göç etme olgusu üzerine odaklanır. Bu nedenle de mikro politik bir eleştiri biçimi olarak göç etme eyleminin (yerinden olma) gündelik hayatın değişimi, kesintiye uğratılması, yerinden edilmesi gayesini anlama çabasına dayanır. Bu yerinden olma hareketliliği, klasik göç teorilerinin ötesinde yaşamın sorgulanmasına ve sonrasında arzulanan değişimin neden olduğu göçebe düşünce ve hareketi ifade eder. Göçebe bir düşüncenin arzusuna dayanan ve arzunun sonucunda ortaya çlkan bir toplumsal olgu olarak ele alındığında ilgili bazı göç teorilerine de değinmek gerekir. Özellikle göçün itici ve çekici nedenleri, çatışmacı durumlar, göçmeler arasında kurulan toplumsal ağlar, ortak firsatlar ve beklentiler, merkez-çevre ilişkisi ve bağımlılık teorileri, göç etme arzusunu ve davranışını şekillenmesinde ve yönünün anlaşılmasında açıklayıcı olan bakış açıları sunar. $\mathrm{Bu}$ nedenle göçün teorik literatürünü uzun uzun tartışmak yerine çalışmanın temel problematiği ve odaklandığı konu ile ilgili açıklayıcı olabilen klasik ve çağdaş teorileri kısaca hatırlamak yeterli olacaktır.

Göç teorilerinin genel olarak odaklandıkları temel unsurular göçün kökenleri, göç akımlarının yönü ve sürekliliği; göçmen emeğinin kullanımı ve göçmenlerin sosyo-kültürel uyumudur. Dolayısıyla göç çalışmalarının amacı da bu unsurları açıklayabilmektir. Klasik ve çağdaş tüm göç teorilerini bir arada ele almanın zorunluğu, günümüzdeki göç hareketliliğinin oldukça karmaşık bir niteliğe sahip olmasındandır. Bu nedenle tüm göç teorileri birbirini dışlamaktan öte ancak kapsayıcı bir yaklaşımla, göç vakalarını açıklama yetisine sahip olabilir. Tüm bu göç teorilerinin, herhangi bir hareketliliği daha net anlamak ve açıllayabilmek için sosyoloji teorileri ile ilişkili bir çerçevede ele almak önemli olabilir. Özellikle sosyal sistemler, çatışma ve gündelik hayat teorileri hem sistemin bir gereği hem de gündelik hayatın dönüşümü üzerinden insanların vermiş oldukları göç etme kararlarını daha anlaşılır kılabilir. 
İlk göç çalışmaları sanayileşme ve beraberinde sanayi alanlarına doğru ortaya çıkan göç hareketleri üzerine yoğunlaşır. Kavramsal tartışmalarla başlayan klasik göç çalışmaları, göç modellerinin ve tipolojilerinin geliştirilmesiyle devam eder (Ravenstein, 1885-1889; Lee, 1966; Peterson 1958). Klasik teorilerin insanların neden göç ettikleri üzerine odaklanırken daha çok ekonomik nedenlere ve sosyal beklentiler üzerine odaklandıkları görülür. Göç hareketliliğindeki en belirleyici etkenlerin kaynak ülke ve hedef ülke arasındaki itici ve çekici nedenlerin olduğu görülür. Çağdaş göç teorilerine bakıldığında ise değişen sosyo-ekonomik koşullarla birlikte göç hareketliliğinin oldukça karmaşık bir hale dönüştüğü üzerine odaklanır ve insanların göç etme düşüncesi ve davranışlarında belirleyici olan doğrudan ve dolaylı bir etken üzerine odaklanarak modellemeler ve tipolojiler geliştirmeye çalışıldığı görülür. 1940'larda göç olgusunda önemli olan noktalar, göç edilecek mesafe, göç edilecek yerdeki imkânlar ve bu imkânların sayısı üzerine odaklanan Kesişen Firsatlar Teorisi, daha mikro çerçevede bireylerin göç hareketliliği içinde kararlarını ve bu kararlara neden olan durumlar üzerine yoğunlaşmakta ve göçmen olarak bireyi bir aktör olarak öne çıkarmaktadır. Stouffer'a göre göç çalışmalarında, göç edilecek yerin/ hedeflenen yerin çekim etkisi üzerinde daha fazla durulmalıdır. İki farklı merkezdeki çekim etkileri, göç edilecek yerle çekim merkezi arasındaki mesafe dikkate alınarak analiz yapılmalıdır (Stouffer, 1940: 846; Özcan, 2017: 199). Böylesine bir çekim etkisi, daha iyi bir yaşam arzunun göçün önemli hareket ettirici bir unsur olduğuna dikkat çeker.

Bir diğer önemli göç teorisi olan Merkez - Çevre / Bağımlılık Teorisi'ne göre (Samir Amin, Immanuel Wallerstein, Andre Gunder Frank gibi) göç sürecinde kaynak ve hedef ülkeleri, merkez ve çevre ülkeler olarak ekonomik gelişmişlik düzeylerine göre tanımlar ve bu durumun göç sürecinde belirleyici bir unsur olarak tanımlar. Bir ülkenin ekonomik olarak gelişmiş̧lik düzeyi, göç hareketliliğinin en önemli nedenidir. Son on yılda Türkiye'den ülke dışına yapılan göç hareketliliğine bakıldığında da göçün yönünün daha gelişmiş ülkelere doğru olması bu teorinin temel iddiasını da doğrular niteliktedir. Dünya genelinde de göç hareketleri ekonomik olarak refah düzeyi daha yüksek olan ülkelere doğru olduğu görülür.

Sosyal sitemler teorisi açısından bakıldığında (Hoffmann-Nowotny, 1981) göç hareketliliği kişinin yaşadığı toplumsal yapıda karş̧laştı̆̆ı siyasal, ekonomik ve toplumsal gerilimler ve daha mikro ölçekte önemsediği sorunları gidermek için ortaya çıkan bir yer değiştirme hareketliliği olarak tartışıldığı görülür.

Açıklayıcı olan bir diğer çağdaş göç teorisi ise göç sistemleri olarak tanımlanan Ağ (network) Teorisi'dir. Wilpert'e göre ağ teorisi “öncü göçmenlerin öncelikle göç veren ve alan toplumları birbirine bağlayan bir altyapı oluş̧turmalarına dayanır ve bu bağlantı göç veren toplumdaki diğer bireylere göçme olanağı (ve cesareti) sağlar. Yeni göç dalgaları, kurulmuş bu ağı harekete geçirir 
ve sonradan göç edenler ilk gelenlerin tecrübelerinden yararlanırlar. Zamanla göç kendi kendini devam ettiren bir hâl alır" (Çağlayan, 2006: 85). Çünkü böylesine kurulan bir ağ ilişkisi, bu ağdan faydalanarak sonradan göç edenlerin yaşamlarını kolaylaştıran, göç ettikleri yere uyumlarını kolaylaştıran, başlangıçta ekonomik olarak destek olan (yeni ev bulma, ilk aşama kalacak yer bulma vs gibi) olumlu bir etkiye sahiptir. Dolayısıyla ağ ilişkileri göre insanların göç hareketliliğini kolaylaştıran ve göç etmek isteyenlere güç ve cesaret veren bir etkiye sahiptir. Göç kararının verilmesini etkileyen ve kolaylaştıran önemli etkenlerin başında, göç edilmesi düşünülen hedef ülkede yaşayanlarla (akrabalar, arkadaş ve tanıdıklar) kurulan ilişkiler gelir. Bu durum göç etmek isteyen kişiye güç ve güven verir ve cesaretlendirir. Çünkü böylesine kurulan bir ağ ilişkisi, bu ağdan faydalanarak sonradan göç edenlerin yaşamlarını kolaylaştıran, göç ettikleri yere uyumlarını kolaylaştıran, başlangıçta ekonomik olarak destek olan (yeni ev bulma, ilk aşama kalacak yer bulma gibi) olumlu bir etkiye sahiptir. Dolayısıyla ağ ilişkileri göre insanların göç hareketliliğini kolaylaştıran ve göç etmek isteyenlere güç ve cesaret veren bir etkiye sahiptir.

Göç Sistemleri Teorisi ise içinde yaşadığımız küresel koşulların bir sonucu olarak göç hareketliliği sürecindeki iki ülkenin (kaynak ve hedef ülke olarak), göç sürecini belli bir yasal düzen çerçevesinde kurguladıkları görülür. Göç sebebiyle hem çıkış hem de varış noktalarının sosyal, kültürel, ekonomik ve kurumsal koşulların değiştiği, göç sürecinin etkisinde özgün bir gelişim alanının ortaya çlktığı şeklindedir (Özcan, 2016: 203). Nitelikli işgücünün İngiltere'ye yerleşmesi ve iş kurması amacıyla 1963 yılında Avrupa Ekonomik Topluluğu (AET) ve Türkiye arasında imzalanan Ankara Antlaşması ile göç eden işgücünün, bu göç sistemleri teorisi ile açıklanması mümkündür. Zira yaşam koşullarını iyileştirmek için İngiltere’ye göç etmek isteyen Türkiye vatandaşlarının ilk başvuru noktası bu antlaşmadır.

Göçmenler arasındaki ilişkiler ağı, göçmenlerin yeni yerleştikleri ülkeler, eski göçmenler, yeni göçmenler ve göçmen olmayan kişiler arasında kurulan ortak köken, soy ve dostluğa dayanan bağlar üzerinden oluşur (Özcan, 2016: 205). $\mathrm{Bu}$ ilişki ağlarının varlığı, insanlar için göçü hareketliliğini çekici kılan, göç sürecinde yaşanan zorlukları kolaylaştıran ve göç sonrası topluma uyum sürecini hızlandıran bir etkiye sahiptir. Bu ilişkiler ağı ayrıca göç düşüncesinde ve eyleminde olan insanların sosyal sermayesi olarak da tanımlanmaktadır.

Benzer çağdaş göç teorileri arasında Hareketlilik Geçiş Hipotezi, Dual İşgücü Piyasası Teorisi, İşgücü Göçünün Yeni Ekonomisi Teorisi, Davranışsal Model, Kurumsal Teori, Birikimli Nedensellik ve Ulusaşırı Göç Teorilerinin de oldukça yoğun bir biçimde tartışıldığı görülür (Özcan, 2016). Tüm bu çağdaş teoriler perspektifinden bakıldığında, göç sürecinde en çok tartışılan mesele işgücü ve işgücünün göç nedenleri ve göç sonrası yaşanan beklenti ve uyum süreçleridir. İnsanların gündelik hayatlarına ilişkin beklentileri ve isteklerinin şekillendirdiği bu göç hareketliliği, sonrasında da yine gündelik hayatta 
görülen yaşanan zorlukları da beraberinde getirir. Çünkü içinde olduğumuz dönem göç ve göçmen olgularına olumsuz bir anlam yüklemekte ve göçmen tanımlaması ise göç alan ülkelerde pejoratif ve dışlayan bir anlama ve ayrımcllığa da neden olabilmektedir.

\section{Bir Gündelik Hayat Eleștirisi: Tekillik ve Göç}

Önemli olan otoriter birleșme değil, bir tür sonsuz saçılmadır (Deleuze, 2002: 432).

Gündelik hayat, mikro politik bir eylem ve bir direniş olarak nitelikli iş gücünün göç hareketliliğinin ya da kişiyi yeni arayışlara yönelten kaçışların nedeni ve temel hareket noktasıdır. Gündelik hayata dair yöneltilen eleștiriler, farklılıkların gittikçe kaybolup birbirine benzediği aynılaşan bir toplumsal yapının eleştirisidir. Bu eleştiri, toplumun çoğulcu yapısını baskılayan ve tekillikleri görmezden gelip, yok sayan bir toplumsal dönüşüme dair bir eleștiridir. Ayrıca yaşam tarzlarındaki, düşünsel ve kültürel çeşitliliğin yok olmasına yönelik eleştiriler olmasının yanı sıra, çevresel koşullara dair eleştirileri de barındırır. Bu eleştirinin odak noktasındaki temel amaç her şeyden önce içinde yaşanılan koşulların değiştirebilme beklentisi ve umududur. Bu değişimi gerçekleştiremediğinde ve umudunu yitirdiğinde ise bu umudunu gerçekleștirebileceği yerlere doğru kaçış arayışı içine girer.

Göç fikri ve eylemi aslında, doğal olana aykırı olan sınırlara, kalıplara ve kurallara karşı kendiliğinden bir reddi ortaya koyar. Aslında göç bir direnişin, itirazın, eleştirinin somut hareketliliği olarak karşımızdadır. Savaşa, yaşamsal hakların kısıtlanmasına, bireyin başkalarının amaçları için araçsallaşmasına, fırsatların engellenmesine, sokulmaya çalışılan kalıplara, biçimlendiren kurallara, özgür düşüncenin unutturulmasına karşı bir itirazdır. Tüm bu itirazlar görünür olmaya başladığında da bir hareketlilik, yer değiştirme düşüncesi ve eylemi ortaya çlkmaya başlar. Çünkü bu itirazın eyleme dönüşmesi, itiraz edilen sistemin sunduğu imkânlarla ya da sistemin açığı bulunduğunda mümkün olur. Bu imkân, düzenli göç sistemi içinde olabildiği gibi sığınma talebi istemek ya da yasa dışı yollardan kaçarak da yaratılabilir. Öncesinde düşünsel olarak ortaya çıkan eleştirel bir sorgulama ve reddediş olarak tanımladığımız göçebelik meselesini Göçebe Özneler (Nomadic Subjets) adlı kitabında Braidotti şöyle tanımlar:

Göçebelik, toplumsal olarak kodlanmış düşünce ve davranış biçimlerine yerleşmeyi reddeden eleştirel bilince atıfta bulunur. Bütün göçebeler seyyah değildir; en muhteşem gezilerden bazıları, kişinin kendi yaşam ortamından fiziksel olarak dışarı adım atmasıyla gerçekleşebilir. Göçebe hali tanımlayan şey geleneksel düzenlerin ters yüz edilmesi ve bilinçlenme faaliyetidir, seyahat etme eylemi değildir (2017: 39-40). Göçebelik, sınırların olmadığına dair bir akışkanlık değil, sınırların sabit olmadığına dair bir farkındalıktır (2017: 93). 
Gündelik hayatın eleştirisini içinde barındıran ve dönüşüm amacında olan göç düşüncesi, motivasyonu ve hareketliliği, gündelik hayat içinde kendi mikro politikasını geliştirerek, bir direniş formu ortaya koyar. Bu direniş formu gündelik olanın sıradan, basit ve tekil unsurlarına dayanır. Bu unsurlar, duygusal ve çevresel odak noktaları olarak ikiye ayırmak mümkündür. Duygusal odaklar, kişinin içinde bulunduğu toplumda doğrudan maruz kalmasa da çevresinde yaşadığı olaylar karşısında mutsuz, huzursuz, güvensiz, tedirgin hissetmesi; çevresel odaklar ise yoğun kentleşme, çevresel koşulların tahrip edilmesi gibi sorunlara dayanır. Bu yapısal sorunlar odağında düşünüldüğünde göç (Hoffmann-Nowotny, 1981), kişinin yaşadığı toplumda karşılaştığı yasal gerilimleri (iktidar sorunları) ya da bireyin kendince önemli gördüğ̈ sorunları (prestij sorunları gibi) gidermek istemesi sonucu ortaya çıkan yer değiştirme hareketlilikleridir (Özcan, 2016: 205). Dolayısıyla göç, kişinin içinde yaşadığı toplumsal yapı ile çatışma halinde olmasının bir sonucu olarak ortaya çıkar. Buna göre çatışmanın nedeni kişinin yaşadığı yerde kendini güvende hissetmemesi ve tedirginliğidir. Çatışma, tüm toplumsal gruplarda ve ilişkilerde görülebilir. Dahrendorf'a göre aile içi ilişkilerden siyasi ve ekonomik ilişkilere göre çatışma durumu gözlemlemek mümkündür (Dahrendorf, 1958). Burada çatışma tedirginlik, güvensizlik, uyumsuzluk olarak da ortaya çıkar. Dolayısıyla çatışmadan kastedilen şey kişinin ihtiyaçları, arzuları, talepleri ve bulundukları ortamın onlara sunabildikleri arasındaki yaşanan uyumsuzluklardır. Böyle bir uyumsuzluk olduğunda kişiler kendilerini güvende hissetmezler ya da başka bir ifadeyle güvensizlik algısı oluşur (Sirkeci, 2019: 26). Bu güvensizlik, yaşananlar sonucu şimdiye ve geleceğe dair kendini (ve yakın çevresini) güvende hissetmeme duygusudur. Dolayısıyla sosyal sistemeler ve çatışmacı teoriye göre göçe neden olan en önemli etken içinde yaşanılan topluma (toplumsal yapıya / sisteme) duyulan güvensizlik hissidir. Bunun sonucunda kişi, kendini ve yakın çevresini daha güvende hissedeceği yere göç etmek ister. $\mathrm{Bu}$ güvensizlik hissi, gündelik hayatın sürdürülemez hale gelmesine, böylece kişinin kendi gündelik hayatını sorgulamasına ve yerinden sarmasına neden olur. Çünkü arzular, istekler, ihtiyaçlar öncelikle gündelik hayatta zuhur eder.

Lefebvre'e göre gündelik hayat, arzuların izlerinin sürüldügü, önceden biçimlendirilmiş ihtiyaçların ne olduğunun tahmin edildiği örgütlü ve itina ile incelenen bir alandır (Lefebvre, 2014: 86). Gündelik hayat, bir denge yeridir; aynı zamanda tehdit edici dengesizliklerin ortaya çıktığı bir yerdir. Böyle bir toplumda devrim, insanlar gündelik hayatlarını sürdüremez hale geldiklerinde başlar (Lefevbre, 2014: 44). Gündelik hayat her şeyden önce bütünlüklü bir tutarlılığa sahip değildir. Fakat iktidar tarafından gündelik hayat içinde aynılaştıran bir baskı mekanizması kurulabilir. Bu durum ise bireyin farkına/ farklılığına içkin olan tekillikler karşısında bir tehdit oluşturur. Bu noktada ise gündelik olanın eleștirisi başlar. Gündelik hayat, olağan, sıradan ve basit olandır. Onun olağan üstü tarafının keşfi ise beraberinde devrimci tarafının 
keşfedilmesini sağlar. Bu tarafın keşfedilmesi ise gündelik hayatın bir bütün olarak algılanması ve değişimin buradan başlaması gereğini ortaya çıkarır.

Gündelik hayatın eleştirisi ve direnme odakları, tekil düşüncenin varlığı ve bunu koruma tavrıyla şekillenir. Burada tartışılacak olan tekil düşünce ve tekillik, tikel ile çoğul arasında kolektif bir yere sahiptir. Her bir insanı çokluk olarak ele alır ve tekil olan birey değil onun çokluğudur; her bir bireyleşme eğilimi kolektif olmaya devam etmektedir. Tekil Düşünce 7 çoğulluğumuzu göstermektedir (Akay, 1999: 8). Burada, tekil, tek olan anlamına gelmemektedir. Tersine çoğul olanın ve hatta daha da öteye giderek, çoğul ve tekil olanın da daha fazlasını oluşturan "çokluk" düşüncesidir. Tek ve çok diyalektiğinden de öteye, çokluk, tekil düşüncenin önemli karakterlerinden biridir. Çünkü tekil düşünce kişinin tek olmadığını ve daima kolektif düzenlemelerin var olduğunu, bireyselin kişi olmaktan ayrı bir şey olduğunu ve hiçbir bireyselliğin bağdaşık olamayacağını, ayrışıklıklardan meydana geldiğini anlatmak istemektedir. Tek merkezciliğin kırıldığı, merkezin daima yer değiștirdiği ve hatta merkez biçiminin bile biçimsiz veya biçimi belirlenemeyen bir biçimden oluştuğu (in- formel) bir düşüncenin ortaya çıkışı, tekil düşüncenin vakasıdır (Akay, 1999, s.15). Bu tekil düşünce, bir "oluş"u (becoming) gerektirir: Azınlık-oluş, göçebe-oluş, kadın-oluş, insan-oluş vs gibi. Gündelik hayatın tekil bir bakışla sorgulanması ve kişinin kendini amaçsal olarak tanımlayabilmesi kendi "var-oluş"unu gerçekleștiren bir oluş sürecini başlatır. Bu ise "göçebe düşünce"nin ortaya çıkışıdır.

\section{Rutini Bozan “Göçebe Düşünce” ve Sınırları Aşan Arzular}

"Sürgündekiler sinırları aşar ve düşünce ile deneyimin önündeki engelleri parçalarlar" (Said, 1990: 365).

“... akış daima arzuya aittir” (Deleuze \& Guattari, 1980: 219).

Göç, düzenli ve saf olarak algılanan sabit sınırları aşan bir "akış"tır. Deleuze'e göre sabit sınırları aşmak, gitmek, kaçıp kurtulmak, bir çizgi çizmektir. Kaçış çizgisi yersizyurdsuzlaşmaktır. Kaçmak, değişim umudunun tamamen yitirilmesi değildir. Deleuze ve Parnet'e göre kaçmak, eylemlerini terk etmek değildir, kaçmaktan daha eylem dolu bir şey yoktur. Kaçmak, molar özdeşlik çizgilerinden uzaklaşmak, yaşamı üretmek ve kendine yeni bir mücadele alanı bulmaktır (1990: 59). Eğer eylemler, ait olunan yapı içinde beklenen değişimi sağlayamıyorsa, bir sonraki aşama ise ait olunan yapının terk edilmesi ve beklentilerin başka bir yapıda aranmasını gerektirir. Bu ise eylemin yok olması değil, gerçekleştirildiği mekanın değişimi anlamına gelir ve bu durum ise bir akışa dâhil olmak demektir.

Seyahat, göç ve hareket daima bizi mirasımızın sınırlarıyla karşı karşıya getirir. Bu karşılaşmadan geri çekilmeyi tercih edebilir ve yalnızca eski görüş-

7 Türkçe'ye tekil sözcügünü "singulier"den çevrilmiştir. Aslında, buradaki anlamıyla "ayrıksı" uygun düşecek; yani ender olan ve diğerlerine benzemeyen anlamını taşıyarak, farklılığını doğrulayan bir düşünce anlamını taşır (Akay, 1999: 15). 
lerimizi onaylayan yerlerde kalabiliriz. Bu durumda öteki taraftaki her şey karanlıkta kalmaya ve belirsizliğini korumaya devam edecektir. Öte yandan ise tersine bir tercihle kendimizi bırakabilir, hiçbir şeyden çekinmeden her şeyin üstüne gidebilir ve o zamana dek yaşamaya alışageldiğimiz dünyadan çok daha geniş bir dünyanın meydan okumalarına karşılık verebiliriz. İkinci yolu seçmek, bizi o zamana dek belli bir merkezde tutan bağ ve istikametleri ortadan kaldırmayı gerektirmektedir. Bu seçim bir dizi soruyla uzam anlayışımızın düzenini bozmak ve işlemesini kesintiye uğratmak demektir. Böylelikle alışılmış ve benimsenmiş bir anlayışın zorunlu olarak herkesçe kabul edilen bir anlayış olmadığı ortaya çıkar (Derrida, 1977: 18 akt. Chambers, 2014: 162). Bunun farkında varmak ve daha zorlu olan yolu tercih etmek ise kaçınılmaz olarak eleştirel bir tavrın ve söylemin ortaya çıkmasına ihtiyaç duyar. Ait olunan toplumsal yapıdaki değişim ise ancak böylesine bir bakışla mümkün olabilir. Bu zihinsel olarak bir göçebelik anlamına gelir ve eğer bu tavır başarılı olamıyorsa artık kişinin fiziksel olarak hareketliliği kaçınılmaz bir hal alır. $\mathrm{Bu}$ göçebe hal ise bireyin kendini gerçekleştirme, kendi amacını ortaya koyma sürecinde kaçınılmaz bir zorunluluğa dönüşür ve böylece kendine dair eleştirel bir dil oluşur. Ancak kendi deneyimine dayanan ve kendi "fark"ını oluşturan tekilliğini (yani kendi "var-oluş"unu) ancak böyle kurabilir ve koruyabilir.

Kültürel sınırlar ve geçişlerle birlikte göç, aynı zamanda pek çok çağdaş akıl yürütmenin biçimine dair bir meseledir. Çünkü göçerlik ve sürgün, Edward Said'in de söylediği gibi "kesintili bir var olma durumu"dur ve geride bıraktığımız yerle bir kavgaya tutuşma biçimidir. Bu kesintili var olma durumu, öncelikle gündelik hayatın kesintiye uğratılmasıyla başlar. Çünkü gündelik hayatın güvenliğine kapatan sınır ve bariyerleri aynı zamanda birer hapishane olabilirler. Zaten bunlar genellikle akla ya da zorunluluğa dayanmayan zeminlerde savunulurlar. "Sürgündekiler sınırları aşar ve düşünce ile deneyimin önündeki engelleri parçalarlar" (Said, 1990: 365 akt. Chambers, 2014: 13). Böyle bir yolculuk, kalkış noktası kaybolan yolculuğun bizzat referans noktalarını da ortadan kaldıran sürekli bir sorgulama biçimini alır. Sürgün asli bir evinin olduğunu ve en sonunda dönüp dolaşıp oraya varacağını farz etse de yolculuk esnasında karşılaşılan sorunlar böyle bir yolculuk planının kapsamını tamamen değiştirir. Asli bir ev ve eve dönüş varsayımlarını devam ettirme olasılığı giderek zayıflar ve sonunda kaybolur (Chambers, 2014: 14). Buradaki sürgün olma / sürgünde olma hali bir göçebe olma halidir. Sürgün olma halinde kişi "yerinden edilir", göçebe durumda ise kişi "yerinden olur." Dolayısıyla her iki durumda da işleyen bir siyaset vardır. Çünkü molar bir yapı içinde ortaya çıkan moleküler bir yapı/biçim, gündelik hayat içindeki mikro-politik bir siyaseti, bir direnme biçimini gerektirir. Mikro-politik bir direnme biçimi ise tekillik çerçevesinde kendi kaçış çizgilerini, akışını yaratır ve olayını gerçekleștirir. Akış her zaman arzuya ait olan ve arzunun neden olduğu bir hareketliliktir. 
Collins'e göre (2018), göçü açıklarken arzuya odaklanmak, göçün hiçbir zaman o kadar da sınırlı olmadığını ve göçmenlerin bir takım düzenlemelere rağmen kendi hareketliliklerini kesinlikle yönlendirebildiklerine işaret etmektedir. Buna göre göçe "karar verme" tekil bir anda ortaya çıkmaz, ancak geçmiş-şimdi-gelecek boyunca inşa edilen bir süreç olarak kavranabilir (akt. Sirkeci, 2019, s.26). Özellikle son yirmi yılda öne çıkmış olan arzu 'aspiration' yaklaşımı, göçmenlerin başarmak istedikleri hedefler yüzünden yola çıktıklarını ifade eder. Bu yaklaşıma göre insanlar hayatlarına ilişkin genel arzu ve istekleri bağlamında hedef ülkelerdeki yaşam niteliklerini kendi yaşamları ile kıyaslarlar. Böylece göç etme yeterlikleri ve kapasiteleri ve hayata ilişkin arzuları göç kararını şekillendirir (De Haas, 2010; Carling \& Schewel, 2018; akt. Sirkeci et al., 2019: 26). Gündelik hayatın eleștirisine dayanan daha iyi bir yaşam arzusu ve beklentisi insanları göçe heveslendiren önemli bir etkendir. Elbette böylesine nedenlere dayanan göç hareketliliği, başka hayatların var olduğu bilgisine ve deneyimine sahip olmaya dayanır. Bu durum, göç edilmek istenen ülkedeki yaşam koşullarına bilen, belli bir süre orada yaşamış olan ve arzuladığı yaşamı deneyimlemiş olan kişinin düşüncesinde oluşan bir hareket etme itkisidir.

\section{Bir Deneyim Meselesi olarak "Yerinden OIma"/Göç Edebilme}

Braidotti'ye göre performatif bir imge ve varlık olarak göçebe özne, deneyimin farklı düzeylerini bir araya getirme imkânına sahiptir (2017: 43). Deneyimle birlikte ortaya çıkan yerinden olma düşüncesi, her şeyden önce kendilik kaygısı ile kendi var oluşunu gerçekleştirme beklentisine dayanır. Maffesoli'ye göre sadece uzağa gidebilen tohumların verimli olma şansı vardır. Gövdenin hemen yakınına düşenlerin hiçbir açılma ve gelişme şansı yoktur. Köklerden, ölülerin toprağından ne kadar uzaklaşırsak o kadar zenginleşiriz, ama bu maddi olmayan bir zenginliktir. Daha iyi gelişmek için hafiflemek, yeniden uyum sağlamak için arınmak, kimi köklerden kurtulmak gerekir. 0 halde göçebelik, bir çeşit disiplindir. Daha iyi olmanın, rahat olmanın egzersizidir (Maffesoli, 2014: 157-158). Maffesoli'nin köklerin, yuvanın, ailenin “ölülerin toprağının" uzağında olmanın ifade ettiği köksüzleşme böyle bir güce sahiptir. Göçebe anlayış, tek biçimciliğin karşısında kimliklerin ihlali ve toplumsal alanda etkileyici olan kodların bozulması üzerine kuruludur. Braidotti'ye göre göçebelik, kimliğin yapı sökümüne, kendiliğin molekülerleşmesine dönük baş döndürücü bir ilerlemedir (2017: 65). Yaşamsal bir deneyim sağladığı böylesine bir göçebe düşünce her şeyden önce geleneksel olanın ve gündelik hayatı baskılayan aynılaştıran iktidar odaklarının alaşağı edilmesi ve farkındalığın güçlenmesidir. Bu farkındalık ve tekilliğin görünürlüğü değişimi arzular ve arzularını gerçekleştirmek için de kaçış çizgileri arar.

Lefebvre'e göre toplumsal deneyimin sağladığı en önemli şey sağladığı motivasyonlarla kazandırdığı sınırsız arzudur. Bu deneyim, dağınık, müphem ve gerçek bir şeyi belirtmektedir. Motivasyonları tuhaf olmakla birlikte, sayısız 
arzu vardır (2013: 15). Ve arzuları gerçekleştirmek için çabalarız, harekete geçeriz, arayışa girer ve kaçış çizgileri buluruz. Fakat başka bir şey olmak için olduğumuz şeyi terk etmeyiz (öykünme, özdeşleşme), başka bir yaşama ve duyumsama tarzı bizim yaşama ve duyumsama tarzımıza dadanır ya da onun içinde sarmalanır ve onu kaçırır (Zourabichvili, 2011: 120). Dolayısıyla olduğumuz şeyden başka bir şeye dönüşmemek için kaçarız ya da var olduğumuz, inandığımız şeyi korumak / yaşatmak için kaçarız. Yani toplumsal alanda farkına vardığımız tekilliğimizi yaşatmak için, çatışarak onu kaybetmemek için, iktidar odaklarının altında görünmez olmasını engellemek için kaçarız.

Her düzenin "kaçış çizgileri" vardır ve bu kaçış çizgileri her şeyden önce mikro politik bir biçimde gündelik hayatta karşılık bulur. Öncelikle toplumsal yapıyı aynı ve tek bir yapı olarak gören anlayış, gündelik hayat içinde kültürleri statik ve saf gruplar olarak yerleştirmeye çalışırken, her zaman "yer değiştirmiş" ve "yerinden edilen" ve bu oluşumlara karşı gelen, onları düzensizleștiren akışlar ve kaçış çizgilerini görmezden gelir. Kaçış çizgilerinin üzerine kurulduğu "akışlar (akış mekanizmaları)", göç politikalarının homojen ve sabit kurgularına karşı, melez ve çoğunlukla görünmeyen fakat yine de etkili olan karşıt kutbu oluştururlar (Diken, 2007: 43). Bu akışlar ve kaçış çizgileri, gündelik hayatın aynılığını, totaliter yapısını dönüştürme amacını taşır ve akışlar her şeyden önce arzunun neden olduğu hareketi ifade eder. Akışı ifade eden bu hareketin çıkış noktası ise deneyimlerdir. Akış mekanizmaları üzerinde kendine bir kaçış güzergahı bulan deneyimin kendisi gündelik hayatı sarsar, kesintiye uğratır ve sonrasında yerinden eder.

Pontalis hareketi deneyiminin merkezine koyar: yaşamamız ve kendimizi özgür düşünebilmemiz için birçok uzama ihtiyacımız vardır ve biz uzamdan diğerine geçebilme imkânımız olmalıdır. Ayrıca Pontalis, bir dilden öbürüne, bir kültürden öbürüne, bir bilgiden öbürüne geçebilme halini "göçebilme kapasitesi" olarak tanımlar (Pontalis, 1993: 709 akt. Aksoy, 207: 442). Göç edebilme hali kişiyi hem varlıksal olarak hem de yaşamsal olarak özgür kılan bir haldir. Kişi göç edebilme hali ile her şeyden önce kendi "deneyim alanını" genişletir. Böylece göç hareketi, kişiyi ve yaşamını özgürleștiren ve zenginleştiren bir deneyim alanıdır. Çünkü deneyimi arttıran ve alanını genişleten, kişiyi ve yaşamını özgürleştiren şey, farklı deneyimlerle karşı karşıya gelme ve hatta çatışabilme hali ve ihtimalidir. Burada Ulrich Beck, kozmopolit perspektifin tamamlayıcı unsurlardan biri olarak "diyalojik tahayyül” ifadesini kullanır. Ona göre bir insanın kendi hayatında kültürlerin ve akıl sistemlerinin çatışmasını yaşaması... bireyin deneyiminde birbiriyle çatışan hayat biçimlerinin bir arada olması, dolayısıyla karşılaştırma yapma, düşünme, eleştirme, anlama, çelişkili ama kesin olan şeyleri bir araya getirmenin yaşamsal bir öneme sahip olmasıdır. Yani Beck'in diyalojik tahayyül kavramından kastettiği şey bireyin deneyiminde birbiriyle çatışan, karşı olan yaşam biçimlerinin bir arada olmasıdır (Beck, 2002: 18). Yani bu diyalojik tahayyül çoğulluğu oluşturan ve çoğulluğun teminatı olan tekilliklerle sağlanır. 
Tekillikleri koruma amacında olan, bu göçebe olma hali beraberinde gündelik hayatta tanımlanan tüm kimlik ve değerleri, alışkanlıkları alt üst etmeye dönük bir tavrı da ortaya koyar. Maffesoli'ye göre bu çağdaş göçebelik hali kimliği zayıflatır, doğayla kaynaşır, daha yoğun ve sezilemez bir toplumsal bağı yeniden icat eder (Maffesoli, 2011: 16). Birey her şeyden önce sahip olduğu kimlikleri aşabilme kapasitesine sahiptir. Dolayısıyla bu kimliklerin ötesine geçebilme hali, bireyin göç algısına ve hareketliliğine sahip olduğu kimlikler ekseninde değil yaşadığı deneyimler ekseninde bakmayı gerektirir. Yani olayı yaratan, olaya neden olan şey deneyimin sağladığı farktır. Farkı oluşturan şey de tekilliklerdir. Deneyim ya da deneyim yaşayan özne kavramının tamamlayıcısı olan bir diğer kavram ise düşünme kavramıdır. Basit anlamda deneyim süreci kendisini düzenleyen, anlamlandıran bir düşünme sürecinden geçmek durumundadır. Burada düşünme, rasyonel ve soyut bir kategori değil, en geniş anlamıyla, ayırdına varmadan duygular repertuarına kadar uzanan, düşünme ve duygulanma, isteme ve arzu etmeyi içeren bir kavram olarak ele alınmaktadır (Turner, 1986; akt. Aksoy, 2007: 432).

Elbette bu göç etme, gitme fikri bir anda ortaya çıkan bir durum olmaktan öte, uzunca bir süre zihinsel olarak karar verme süreci sonrasında verilen bir karardır. Bu süreç ise göçebelik düşüncesini ortaya çıkarır. Göçebe düşüncenin sadece bir kısmı fiziksel harekete, göç hareketine dönüşebilmektedir. Bu süreçte özne, sınırların olduğu her yerde bu sınırların ötesinde başka seslerin, başka bedenlerin, başka düşüncelerin, başka yaşamların ve başka dünyaların olduğunu kavramaya başlar. Arzuların peșinde koşarak sınırları aşan özne, kendi sınırlarının dışındaki dünyayı, umut ettiği dünyayı deneyimleme süreci içinde kendi akışını yaratır. Böylece yeni bir arayış, aranan yeni bir yer belirler: $\mathrm{Bu}$, başka bir dünyanın, başka bir yaşamın da mümkün olduğu başka bir yer, başka bir dünya, başka bir gelecek ihtimalidir. Fakat böylesine bir göç sürecinde (diğer göç hareketlerinden farklı olarak) geri dönme fikri yoktur ya da çoktan (ya da göç sürecinde, yaşadığı deneyimlere bağlı olarak yavaş yavaş) kaybolmuştur/kaybedilmiştir. Bu kişileri göçebe olarak tanımlamak mümkündür. Çünkü Deleuze'e göre bu kişileri göçebe yapan şey, fiziksel hareketlerinden öte sahip oldukları tekillikleridir; verili bir toplumsal düzende kendilerine tahsis edilen yerlere "karışıp gitmeyi reddettikleri için göçebe olurlar" (Deleuze \& Guattari, 1980: 138). Aynı olmayı reddedip, kendi "fark"lılıklarını vurguladıkları ve bu "fark"lılıklardan vazgeçmedikleri için "göçebe"dirler. Sahip oldukları toplumsal konfordan vazgeçerek, yerinden olmayı tercih ederler (ya da buna razı olurlar). Tekillikleri çoğul yapıya uymaz; çoğul yapı artık rahatsız eder ve arzuladıkları hayatlara ulaşmak için kaçış çizgileri ararlar. Akış içinde düşüncede ve eylemde yer değiştirmeyi isterler (ya da yer değiștirmek bir zorunluluk haline gelir ve yerlerinden olurlar) ve böylece göçebe bir sürece dâhil olurlar. Zamanla bir arzuya dönüșen bu yer değiștirme istenci, kendine kaçış çizgileri bularak önce zihinsel olarak, sonrasında da 
Bu kaçma/ ya da arayış istenci kendine alternatif yollar bularak akışı oluşturur. Daha iyi bir yaşam ve dünya arzusunu, kişinin içinde bulunduğu /yaşadığl dünyaya karşı bir direniş, bir karşı oluş olarak tanımlamak mümkündür. Kişi yaşadığı dünyayı / hayatı değiştirmek için kendini bir hareketliliğe dâhil eder. Dâhil olduğu bu hareketlilik içinde bulduğu kaçış çizgileri boyunca sürekli bir arayış içindedir ve onu yersiz yurtsuz kılan şey bu arayış halidir.

Bu "akış"lardan oluşan kaçış ve arayış hareketliliğini "yerinden olma" ve "yerinden edilme" olarak iki kategoriye ayırmak ve bu çerçevede değerlendirmek ve açıklamaya çalışmak gerekir. Yerinden olma ve yerinden edilme ayrımının temelinde biçimsel olarak göç hareketinin gönüllü ve zorunlu olma hali vardır. Fakat derinlemesine bakıldığında ise yerinden olma hali, yaşanılan çevrenin ve toplumsal koşulların kişiyi farkında olmadan göç etme hareketliliği içine sürüklemesidir. Dolayısıyla bireylerin bu hareketliliği ve motivasyonu, derinlemesine incelendiğinde aslında her durumda bir "zorunda kalma" haline denk düşmektedir. Yani "yerinden olma” hali de dolaylı olarak bir zorunluluğa dayanır.

\section{Yerinden Olma ya da Gemileri Yakmak:}

\section{... (Peki) Başka Bir Hayat Mümkün (müdür?)}

Göçebe düşünceyle başlayan gündelik hayatı sorgulama ve değișimi sağlayarak yerinden etme çabası, değişimin gerçekleş(e)mediği durumlarda, kişinin yer değiştirmesiyle karşımıza çıkan bir hareketliliği ortaya çıkarır. Gündelik hayatın baskılayan kuralları, algıları, davranışları, tekilliğini önceleyen birey için çekilmez hale geldiğinde, bunu değiştirme arzusu ve beklentisi belirmeye başlar. Fakat gündelik hayat içindeki kurallarının katı ve sert olması, değişimi zorlaştıran, imkânsız kılan bir etkendir. Bu değişim gerçekleşmediğinde ise bireyin bir yerden başka bir yere doğru fiziksel hareketliliği olarak tanımladığımız göç hareketliliği başlar. Yani gündelik hayatının iktidar odaklarını değiştiremeyen, yerinden edemeyen birey, kendi taşlarını oynatır ve arzuladığı değişim için yerinden olmaya razı olur. Tüm bu düşünce ve hareketlilik biçimi, başka hayatların mümkün olduğu bilgisi ve deneyimiyle ortaya çıkar. Elbette ki bu deneyim, ekonomik ve kültürel (eğitim fırsatları gibi) imkânların varlığıla ortaya çıkabilen bir deneyimdir.

$\mathrm{Bu}$ çalışmanın temel sorunsalı etrafında gerek yurtiçi gerekse yurtdışında (İngiltere örneği olarak) yapılan görüşmelerdeki katılımcıların demografik özelliklerini bakıldığında büyük kentlerde yaşayan, yüksek eğitim almış, toplumsal statüde prestijli işlerde çalışan, belli bir ekonomik yapıya ve mülkiyet gücüne sahip kişilerden oluştuğu görülür. Yurtdışına dair yaşanmış deneyimleri vardır. Çok azının ise hedef ülkedeki ilişkilerine dayanan aktarılmış deneyimleri vardır. Erkekler daha kolay göç edebilmekte ya da bu göç etme fikrini gerçekleştirebilmektedir. Bekar kişiler daha kolay hareket edebilmektedir. Evli ve çocuklu olanlar ise öncelikle çocuklarının daha yaşanılabilir bir çev- 
rede ve daha iyi koşullarda yaşamlarını sürdürme ve daha iyi bir eğitim alma beklentisi ile göç etmeye karar verdikleri görülür. Bunlar göç hareketliliğinin en önemli bağımsız değişkenleridir. Bu özellikler elbette yapılan görüşmecilerin sahip olduğu özellikler çerçevesinde değerlendirilmektedir. Fakat yapılan görüşmelerde göç etme motivasyonlarındaki nedenlerin ve beklentilerin benzerliği, bu çalışma kapsamındaki iddiaları desteklemekte ve hipotezleri doğrulamaktadır.

Göç edeneler ve göç etme düşüncesinde olanların genel tavrı ve eleștirisi, gündelik hayat içinde önemli bir yere sahip olan ve gündelik hayatın görünmez ama bir o kadar da hayatı anlamlandıran önemli odak noktalarına dayanır. Bu odak noktalarının oluşturduğu durum ise daha yaşanabilir bir hayat algısı ve beklentisidir: İlk olarak soyut olan duygular etrafında oluşturulmuş bir algi; sonrasında ise yaşanan çevreye ve birlikteliğe dayanan bir algı. Bu doğrultuda görüşmecilerden gelen en önemli yanıt, huzurlu, güvenli ve yaşanılabilir (hem sosyal ilişkiler açısından hem de çevresel olarak) bir yaşam beklentisi olmuştur. Buradaki huzur ve güvenlik beklentisi sadece kişiyi çevreleyen bir beklenti olmaktan öte toplumsal bir güvenin ve huzurun sağlanması beklentisidir. Çünkü güvenlik, kişinin arzuladığı ama tek başına sağlayamadığı ve içinde yaşanılan toplumun sağlayabileceği bir durumdur.

Uzun yıllar Türkiye'de (İstanbul) Bilgisayar Mühendisliği yapan erkek bir görüşmeci, İngiltere'ye yerleşmeye karar vermiş ve Ankara Antlaşmasına başvurmuş ve bunun sonucunu beklerken bir restoranda kayıt dişı olarak (yaşamını sağlamak adına) basit işler yaparak günlük ihtiyaçlarını karşılamaktadır. Bekar olması ise bu kararı vermesini kolaylaştırmış. Göç etme kararını, kendi algısal deneyimi üzerinden ifade ederken "huzur" ve "güven" kavramları etrafında yaşama bakışını net bir biçimde ortaya koyar:

Ben huzur arıyorum, yaşama dair kaygılı olmak istemiyorum. Buraya geldiğimden beri kendimi ruhen oldukça hafiflemiş hissediyorum. Belki çok sıradan bir iş yapıyorum ama bu bana hiç ağır ve ruhen zor gelmiyor. Çünkü burada ileriye dönük hiçbir kaygım ve güvensizliğim yok. Geleceğe / yarına dair kaygılı olmamak, bugünü daha yaşanabilir kılan bir șey. Sadece benim değil, herkesin bu duygu halinde olması ise bu duygunun burada herkesin sahip olduğu fikrini veriyor ve buna dair güvenim daha da artıyor.

Elbette bu görüşmecinin kararlığı ve her zorlukla baş edebilirim tavrı, İngiltere'ye yeni gelmiş olmanın vermiş olduğu heyecanla olan ilişkisini göz ardı etmemek gerekir. Ayrıca geldiği bölgede kendinden önce göç etmiş olan yakınlarıyla da bir aradadır. Bu bir arada olma (ă̆ teorisine dayanarak) hali, göçün zorluklarını en aza indiren ve kişiye güç ve cesaret veren, olası zorluklara karşı (iş bulamama, dışlanma, ülkeyi özleme gibi) motive eden olumlu bir durumu ortaya koyar. Uzun bir zaman süreci içinde bakıldığında ise planladığı gibi kişinin kendi mesleğini yapma beklentisinin gerçekleşmediği durumlarda da oldukça yaygın olduğu görülüyor. Türkiye'de kimya mühen- 
disi olan ve uzun yıllardır İngiltere'de yaşayan bir görüşmeci, göç eden diğer göçmeler gibi İngiltere'ye kendi mesleğini yapma beklentisiyle geldiğini, önce geçici olarak yaptığı restoran işini sürdürmek zorunda kaldığını anlatırken, toplumun sağladığı güven ortamının kendi mesleğini yapmaktan daha önemli olduğunu yaşayınca anladı̆̆ı şöyle anlatıyor:

Kendi mesleğimi yapma hayaliyle geldim. İngiltere'de kimya mühendisliği yapacaktım. Önce geçici olarak bazı işlerde çalıştım. Bu işler vasıfsız olarak kolayca bulabileceğim işlerdi. Hayata tutunabilmek için bu işleri yaptım. Bazen çok zor geliyordu, çünkü mesleğimi ve konforlu olan hayatımı bırakıp geldim ve sıfırdan başladım. Fakat yabancı olarak burada yüksek meslek gruplarına ait olan meslekleri sürdürmek ve işe kabul edilmek zor olmanın ötesinde imkânsız olduğunu fark ettiğim de ise restoran işini daha kolay yapabileceğime karar verdim. Önemli olan doğru bir yaşam sürmek olduğunu anladığımda kendi mesleğimi yapamamak zor gelmedi. Buradaki yașamın sağladı̆̆ı güven ve konfor, Türkiye'de mesleğimin sağladığı güven, konfor ve zenginlikten daha önemli olduğunu anladığımda, geri dönme düşüncesinden de tamamen vazgeçtim.

Kişinin göç etmeden önce yaşadığı ortamdaki yaşamsal güven ve huzuru sağlayamadığında yıllarca eğitimini aldığı ve bir süre yaptığı mesleğini ve imkânlarını feda edilmesi, bir şekilde kişinin yerinden olmasının önemli bir gerekçesi olarak görülüyor. Bir başka görüşmeci toplumsal yaşamdaki "güvenlik" kavramını referans alarak Türkiye'de kadın olmanın zorlukları üzerinden konuşurken yaşadıklarının göç etme (kaçma) fikrini nasıl kesinleştirdiğini ise kendi deneyimini üzerinden şöyle anlatıyor:

İstanbul'da oldukça kalabalık ve merkezi bir yerde yaşadığım taciz olayı benim için kırılma noktası oldu. Her şeyden önce bir insanın buna nasıl cesaret edebildiği düşüncesi hala aklımın almadığı bir düşünce. Fakat asıl daha kötüsü ise çevredekilerin buna ses çıkarmamaları oldu. Bu cesareti ona, adil olmayan yasalar ve buna ses çıkarmayan toplum veriyor maalesef. Oysa konu klyafetinize, saçınıza, kararlarınıza gelince herkes karışıyor. Onu giyme, bunu yapma, onunla görüşme vs gibi.

Bu örnek her ne kadar kişinin yaşadığı tekil bir örnek olsa da, toplumsal bir alanda bunun yapılabiliyor olması ve tepkisiz kalınması, aslında toplumsal olarak ne kadar alışılmış ve sıradan olduğunun bir göstergesidir. Özellikle ülkemizde artan kadın şiddeti ve tacizlerine dair vakaların giderek artması, bu durumu normalleştiren, sıradan bir hale dönüştürmüştür. Benzer vakaları hiç yaşamamış insanları bile tedirgin eden, korkutan ve güvende olmadığı hissini veren toplumsal bir yaygınlığa da sahiptir. Bu örnek vaka ve etrafinı çevreleyen genel durum, toplumsal alandaki erkek iktidarının mikro bir görünümü olarak belirginleşmekte ve yasa ile olan ilişkisi sorgulandığında (iyi hal indirimleri gibi etkenlerin, yasanın caydırıcı etkisini zedelemesi gibi) ise makro iktidarla olan ilișkisi de belirginleşmektedir. Dolayısıyla her tekil vakanın, toplumsalın içinden türeyen ve onu yansıtan bir parça olduğunu da unutmamak gerekir. 
Evrensel olan yaşamsal ve duygusal gerçeklere vurgu yapan bu görüşme örnekleri, içinde bulundukları topluma dair eleştirilerini ortaya koyuyorlar. Ayrıca bu beklentilerin oluşması ve bunları karşılayan toplumların varlığıyla oluşan bir algı olduğu gerçeğini de göz ardı edilmemelidir. Bu noktada görüşmecilerin hepsi, yaşamlarının belli dönemlerinde, uzun ya da kısa süreli yurt dışında bulunmuş ve bunun mümkün olabildiğini deneyimlemiş kişilerdir. Çünkü başka yaşamların, toplumların farkında olmayan kişinin bunu bir eksiklik olarak görmesi ve onu arzulaması beklenemez. Yani kişinin evrensel değerler noktasında düşünebilmesi, sorgulaması ve eleştirebilmesi, bu farkındalığın oluşmasında ve bunun beklentiye dönüşmesinde önemli bir ayrım noktasıdır. Dolayısıyla arzuyu oluşturan şey, deneyimin kendisidir. Bu durum ise kişinin deneyimlerinin karşılaşması ve çatışmasıyla, değişim ve dönüşüm beklentisini ifade eder. Yani farklı yaşam ve kültürleri deneyimleme fırsatı, kendi beklentilerini daha net bir biçimde ortaya koyabilmesini sağlar. Bu durum ise arzuyu, kaçışı, yersiz yurtsuzlaşmayı dolayısıyla başka deneyimleri beraberinde getirir, dönüşümü gerektirir ve bunu süreklileştirir.

Film sektöründe çalışan, sosyal statü ve ekonomik olarak da iyi bir konuma sahip olan bir diğer kadın görüşmeci ise kazandığı paranın ve işinin sağladığı prestijin Türkiye'de yaşamsal beklentilerini karşılamadığı düşüncesine kapılır kapılmaz, tüm imkânlarını zorlayarak İngiltere'ye yerleşme çabasını ise şöyle anlatıyor:

Uluslararası bir yapım şirketinde iyi bir pozisyonda çalışıyordum. Fakat çalışma koşullarının yoğunluğu, kendi yaşamımı ve yaşamıma bakışımı sorgulamama neden oldu. Elimde var olan birikimimle (çok yoğun çalıştığım için kazandığım parayı harcayacak zamanım olmadığı için biraz birikim yapabilmiştim) göç etmeye karar verdim. Elbette bu kararımı kolaylaştıran ve cesaret veren șey, abimin de burada yaşıyor olmasıdd. Önce sektörde çok basit, sıradan işlerde çalıştım ve şimdi ise serbest olarak çalışlyorum. Yani sektörde bana ihtiyaç oldukça çalışıyorum. Temel düzeyde yaşamımı sürdürmemi sağlıyor ama hayatım bana, yaptığım işe rağmen değil rağmen değil, benimle birlikte aklyor. Buradaki çalışma koșulları ve işe/ çalışana bakış, yaşamın yaşayanın elinde olduğunu ve asıl amacın doğru ve yaşanılabilir bir hayat sürdürmenin olduğunu gösterdi bana. Bu, benim için yaşama dair bakışımı değiștiren ve farkındalığımı oluşturan bir dönüm noktası oldu.

$\mathrm{Bu}$ örnek doğrudan kişinin kendi yaşamını amaç edinmesi ve başkalarının amaçları için araçsallaştırılmamış olan birey kavramına denk gelen bir yaklaşımı ortaya çıkarıyor. Dolayısıyla özneleşme sürecinin bir parçası olan iktidarı ve iktidar odaklarını aşma çabasındaki öznenin, kendi amacını gerçekleştirme beklentisine sahip olan böylece kendini özgürleștirme çabasındaki, yani kendi "var-oluş"unu ortaya koyma çabasındaki bir birey olarak karşımıza çıkarıyor. Ayrıca bu örnek kişinin kendisi için yaşamsal beklentilerini ortaya koyan ve bu beklentiler doğrultusunda hareket ederek bunu oluşturma sürecini gösteriyor. Elbette bu oluş sürecinin tam olarak tamamlanması söz 
konusu değil ama en azından adım adım bunun gerçekleştirilebileceği, bunun mümkün olduğu bir yaşamı hayal etme ve kurgulayabilme firsatı sunar. Ayrıca örneklerin çoğu gösteriyor ki, yaşamsal deneyimler ve bu doğrultuda oluşan yaşamsal beklentiler, bireyin kendi tekilliği etrafında oluşuyor. Böylesi bir tekillik ise ancak çoğulculuğun var olduğu bir toplum yapısı içinde anlamlı hale gelir. Bu noktada Deleuze'un "oluş" olarak kastettiği şey, verili ya da kurulu benliklerimizden sıyrılıp sonunda tam olarak kim ya da ne olacağını bilmediğimiz süreçlere imkân tanıyan potansiyel bir yaşam yaratmaktır. Bir toplum mikro politik olarak moleküler olan kaçış çizgileriyle tanımlanır (Deleuze \& Guattari, 1980: 216). Bu kaçış çizgileri, tekilliklerin dayandığı deneyimle ortaya çıkar. Bir öykünme ya da özdeşleşme olmayan, hatta bunların tüm çerçevesini kaydırıp karmaşıklaştıran “oluş"un amacı, kişinin tanımlanamaz hale gelmesidir (Demirtaş, 2017: 89). Yani tüm kimliklerinin belirsizleşmesidir. Tekillikler ve fark, arzu, kaçış çizgileri, akış ve sonrasında da olayı gerçekleştiren "oluş" süreci, kişiyi kimlik politikalarından yani kişiyi tanımlayan, kişinin kendisini tanımlamasını sağlayan, ayıran ve ayrıştıran kimliklerden kurtarır.

Bireyin içinde yaşadığı toplumla kurduğu deneyimsel bağlar, sıradan ve olağan olanın eleștirilmesi ile birlikte bir farkındalığa neden olur. Bu farkındalık ise rutin sorgulanmasını ve gündelik hayatın eksik ve baskıcı yanlarının fark edilmesi ile birlikte değişimin arzulanmasına dayanır. Gündelik hayatın mekanizmalarının kent alanlarını nasıl tahrip ettiğini, gitme motivasyonuna sahip olan, fakat bir türlü fırsatlarını oluşturamayan bir görüşmeci bu konuda kendi deneyimini şöyle tanımlar:

Çocuğumla bebek arabası ile kaldırımda yürüyemiyorum. Çocuğumla sokağa çıkmaya korkuyorum. Kaldırımlar arabalar tarafından gasp edilmiş durumda ya da planlama çok kötü. Yayalar için ayrılmış kaldırımlar esnaf ve arabalar tarafindan işgal edilmiş durumda. Burada yașamak, en bașından itibaren gasp edilmiş bir hayatı yaşamak gibi.

$\mathrm{Bu}$ örnek, kent politikalarının nasıl kentte yaşayanlara rağmen kurgulandığına ve ortaya çıkan kentin kentte yaşayanların yaşam alanlarını nasıl gasp ettiğini net bir biçimde gösterir. Bu durum, hem toplumsal alanda alışılmış ve öğrenilmiş bir durum olarak daha güçlü olanın (örneğin arabası olanın) güçsüz olanı (örneğin yaya olanı) görmezden geldiğine hem de yasanın buna nasıl izin verdiği sorusunu sorgulatıyor. Benzer bir biçimde bir diğer görüşmeci ise iktidarın sadece yaşamsal alanlarındaki duyguları yok etmesinden öte yaşamını doğrudan tehdit eden unsurları kaybolan "güven" duygusu ile şöyle eleştirir:

Kalitesiz yemek içme meselesi de çok önemli. Sadece restoranlarda değil, marketlerde de aldığımız en ufak ürünler hayatımızı riske atıyor. Tam bir gıda terörizmi ile karş̧ karşıyayız. Denetimsiz her șey. Kurumlar bu konuda o kadar denetimsiz ki, istisnai olan genele yayıllyor ve normal bir hal allyor. 
Elbette tüm bu kentsel ve insana dair tehdit edici, tekinsiz ve güvensiz olan sorunlar, içinde bulunduğumuz dünyanın genel sorunlarıdır. Elbette bu sorunlardan kaçarken, sığındığı yerde de bu sorunlarla karşılaşması oldukça olasıdır. Fakat bireysel algı, bu hareketliliğin, arayışın kendi içindeki umuda sığınan bir anlayışa sahip olduğunu gösteriyor. Bu da demek oluyor ki, göçebe düşünce sonsuz bir hareketliliğe, arayışa, kaçışa neden oluyor. Göçebe kılan şey, sonsuz bir saçılma halidir. Önce düşüncede ve ilk firsatta da hareket halinde bir saçllma, yersiz yurtsuz olma halidir.

Bu örneklerden hareketle, bireyin içinde bulunduğu toplumla kurduğu ilişkinin güvenin kaybolduğu çatışmacı bir biçime dönüşmesi, umudun yitirilmesi ve yitirilen umutla birlikte eksik olanın arzulanmasına doğru oluşan akışlar göçebe düşünceyi ortaya koyar. Deleuze ve Guattari'ye göre arzu devrimini göçebeler yürüteceklerdir bunlar, toplumsal bilinçdışının pürüzsüz mekanını işgal eden insanlardır. Ne zaman başkaldırma, ·ayaklanma ya da devrim varsa, toplumsal varoluşun bir göçebe tarzı oluşur (Goodchild, 2005: 273). Burada bireysel olarak gündelik yaşam içinden çıkan mikro direniş biçimleri, toplumsal alana yayılamadığında kişileri yer değiştirme eğilimine yöneltmektedir. Böylece kişilerin bu arayışları, kendi yaşadıkları coğrafyadan kaçışa neden olduğu görülür. Başka yaşam arayışları bu kişilere "göçebe bir kimlik kazandırır. Bu durum ise kişinin kendi yaşamında gerçekleştirdiği bir devrimdir. Bu konuda kısa bir süreliğine İngiltere'de yaşamış, buradaki yaşamdan etkilenmiş ve burslu olarak buraya geldiği için geri dönmek zorunda kalan bir görüşmeci, "başka bir yaşamla" olan deneyimini şöyle açıklıyor:

Yaşamıma burada devam etmek isterim. Fakat zorunlu hizmetim olduğu için geri dönmek zorundayım. Ayrıca zorunlu olarak ödemem gereken kredilerim var. Bu zorunluluklarımdan kurtulabilirsem, buraya yerleșmek isterim. Evet "gemileri yakacağım" ama ne zaman ve nasıl cesaret edebilirim bilmiyorum. Türkiye'de insanın "zorunluluklar"ından kurtulması çok zor. Umarım döndüğüm de bu kararlılığım değişmez. Çünkü insan ne kadar dirense de bir süre sonra farkında olmadan yaşadığı yere ve o yerin insanlarına benzemeye başlıyor.

Gündelik yaşam içindeki aynı sorunlardan dolayı göç etme fikrinde olan ve göç hareketliliğini gerçekleștirmeyen ya da bir süre bunu ertelemek zorunda kalanların önemli gerekçelerinin başında, kendilerini topluma ve sisteme bağlayan zorunlu/mecburi bağımlılıkları (ekonomik borçluluk, hizmet yükümlülügü, ailevi sorumluluklar gibi) olduğu görülür. Göç hareketliliği içinde olmasalar da bütün yapıdan koptukları, düşünsel olarak göçebe oldukları söylenebilir. Bu zorunluluklarından kurtuldukları anda göç hareketliliğini deneyimleme sürecine dâhil olurlar.

Tekillik düşüncesi ve tekil olanın varlığg, gittikçe aynılaşan ve çoğulcu biçimi yitiren tek tipleşen toplumlarda zamanla yalnızlaşmaya, dışlanmaya, baskıya maruz kalmaya ve tekilliğini yitirmeye başlar ve böylece deneyim kaybolur. Direnemeyen ve deneyimini kaybetmeye başlayan tekil düşünce (yaşam tar- 
zı), çoğunluğa benzemekten başka sadece bir şansı kalır: kaçmak. Ya çoğunluğa benzemeye başlar ya da kaçış yolları arar. Bu noktada ise mevcut toplumsal ve siyasal yapıdaki otoriterleşen durum ve sonucunda da ortaya çlkan totaliter yapı, arayışın ve kaçısın en önemli nedenidir. Türkiye'de ise bu durum, siyasal yapının seküler bir karşıtlık mı barındırdığı sorusunu beraberinde getirir. Mevcut siyasal yönetimin dini bir kimlik ve söylemle, siyasal gücünü kazanmasının yanı sıra bunun daha çok, otoriter yapısı ile söz konusu olduğu düşüncesini de unutmamak gerekir. Çünkü göç etme / kaçma düşüncesi ve eylemi, bu dönemde dini, muhafazakar kimliğe sahip olanlar arasında da gözlemlenen bir durum olması, sekülerlik karşıtlığından öte, tekil yaşamlara karşı uygulanan ya da tekil yaşamların da maruz kaldığı bir baskı sonunda da ortaya çıktığını gösteriyor.

Bu konuda kendisini dini kimliği ile tanımlayan kadın bir görüşmeci yaşadığı ve göç etmek kararında oldukça etkileyici olan kendi deneyimini ve yaşama bakışını şöyle açıklar:

Ben kendimi dindar bir birey olarak tanımlarım. Bu tanımlama kendi yaşam tarzımı açıklar. Dini kurallarla hayatımı planlarım, ibadetlerimi yerine getirmeye çalışırım ve dinimin gerektirdiği ahlak bütünlüğünü de elimden geldiğince korumaya ve bu ahlak çerçevesinde yaşamaya çalışırım. Ülkemde yaşanılan ve insanların maruz kaldığı baskı ve ayrımcılık bir Müslüman olarak beni çok yıpratıyor. Bunların başında çocuklara ve kadınlara karşı işlenen tacizler ve şiddet meselesi. Doğrudan maruz kalmasak bile benim gündelik hayatımı iyice çekilmez hale getirdi. Bunun her an benim de çocuğumun da başıma geleceği düşüncesi dayanılmaz bir șey. Ve sizi buna karşı koruyacak ve savunacak hiçbir şey yok...

Başka bir görüşmeci uzun yıllar çalıştıktan sonra tüm birikimini ortaya koyarak Türkiye'den zor da olsa ayrılma gerekçesini benzer nedenlere dayandırarak yaşanılanların nasıl sıradanlaştığını ve bunlar karşısında insanların nasıl duyarsızlaştığını, duygusuzlaştığını şöyle açıklıyor:

Şiddetle, haksızlıklarla, tacizler ve zorbalıklarla hayatınıza gasp eden bir düzen var ve siz buna zamanla alıșmaya bașlyyorsunuz. Bu haberleri her akșam dizi izler gibi izliyorsunuz. Üzülüyorsunuz, ağllyorsunuz... Dizi bittiğinde de hiçbir șey olmamış gibi kendi hayatınıza dönüyorsunuz. Yani bu kadar normallești ve sıradanlaștı hayatımızda. Ve hiçbirimiz farkında değiliz. Sıra kendimize geldiğinde mi bir șeyler yapma gereği duyacağız. Bu nedenle kendimi ve ailemi korumak için çok sevdiğim akrabalarımdan, ülkemden, arkadaşlarımdan ayrılmak zorunda kaldım. Ama aynı şeylere kendimin, eşimin, çocuğumun maruz kalmasını da göze alamazdım.

Yapılan görüşmelerin odağında göç etme düşüncesinin ve hareketliliğinin nedeni olarak gündelik hayattaki sıradanlaşan, duyarsızlaşan, hayatı tehdit eden, huzuru kaçıran, güvenin kaybolmasına neden olan, tekinsiz olan ve dışarıdan oldukça basit görülen durumların olduğu görülüyor. Göç etme isteğinde olan ve kısmen bu isteği yerine getirmiş olan (tam olarak yerleşme 
henüz gerçekleşmemiş, geçiş sürecinde olan) insanların gündelik hayatlarını "güvensiz" ve "tekinsiz" hale sokan durumlardan kurtulma beklenti, arzu ve istekleri yer almaktadır. Bireyin kontrol edebildiği, tanımlayabildiği ve farklılığını ortaya koyabildiği bir gündelik yaşam pratiği söz konusudur. Bu farklılığı ortaya koyma isteği ve çabası, esas olarak gündelik yaşamın içinden bir direnişi gerektirir. Bu direnişin sebebi ise farklılığı ortaya koyabilecek mekanizmaları işler hale getirebilmek ve çoğunluk içinde homojenliğe karşı bir duruşu ifade eder. Bu durum ise zihinsel olarak bir göçebeliğe karşılık gelir. Eğer kişi yaşadığı coğrafyada böyle bir mekanizma işletemiyorsa, bu sefer coğrafyayı değiştirme isteği, arzusuyla fiziksel olarak bir hareketliliğe geçer. $\mathrm{Bu}$ fiziksel hareketlilik ise artık umudun tükendiği ve gündelik yaşamı saran umutsuzluk, güvensizlik, huzursuzluk ve mutsuzluğun geldiği son noktadır ve kişi artık başka seçeneği olmadığı için gitmek ister. Elbette böylesine bir göç motivasyonun oluşması, yaşadığı yaşamın dışında, alternatif yaşamların, başka yaşam biçimlerinin de mümkün olduğu bilgisine sahip olmasına dayanır. Bu nedenle görüşmecilerin, göç etme isteğinin temelinde, bu alternatif yaşamları bilme, farkında ve tecrübe etmiş olmaları vardır. Bu kişiler yaşamlarını belli dönemlerinde uzun ya da kısa süreli yurt dışında bulunmuş ve böylece kendi yaşamlarını ve gündelik hayatlarını sorgulama ve anlamlandırma fırsatı yakalamış kişilerdir. Burada göçe neden olan şey, kişilerin sahip oldukları tekillikler ve bu tekillikleri koruma arzusudur. Gündelik yaşamın gittikçe kısıtlanması, aynılaşması kendi tekilliklerini önemseyen ve önceleyen kişiler için direnme nedenidir. Bu direniş, yaşadığı yerde kalıp mücadele etmek olabildiği gibi kendi tekilliğini koruyabileceği başka yerlere kaçış olarak da ortaya çıkabilir. Mücadele etmenin anlamsız ve yetersiz olduğunu düşündüğü anda kişi kaçışı seçer ya da bu tekilliğini sürdürebileceği yer arayıșına girer. $\mathrm{Bu}$ yer sadece coğrafi bir mekan değil, aynı zamanda farklılığın / tekilliğin korunabildiği, çoğulculuğun var olabildiği siyasal ve kültürel bir mekandır. Bu nedenle göç etme arzusunda olanların daha iyi bir yaşam beklentisiyle yönleri hep batı toplumları olmuştur. Elbette bunun ilk nedeni ekonomik olarak gelişmişlik seviyesi gösterilebilir. Bağımlılık teorilerine göre göç hareketliliği her zaman çevreden merkez ülkelere, ekonomik olarak daha güçlü ülkelere doğru olmuştur. Çünkü ekonomik refah ve gelişmişlik seviyesi beraberinde toplumsal ve siyasal refahı da sağlayan bir unsurdur.

\section{Sonuca Dair}

\section{"İyi Bir Yaşam Yaşamaya” dair bir hareketlilik}

Arzuyu bir eksiklik olarak düşünmek, arzulanan şeye doğru bir akışı anlaşılır kılar. $\mathrm{Bu}$ ise umudu, güveni, huzuru ve bunları içinde barındıran bir yaşamı arzulamaktır. Her şeyden önce içinde yaşadığı toplumda kendine ait bir yer bulamadığını ya da ait olduğu yerden gittikçe uzaklaştırıldığını (düşünme biçimi ve yaşam tarzı olarak), dışarıda kaldığını düşünen kişi, bu ortama (sosyo-kültürel, siyasal ortama) yabancılaştığını düşündüğü andan itibaren bir 
arayış içinde kendini bulur. Bu arayış ise kendi gündelik yaşamında eksikliğini hissettiği ve arzuladığı bir yaşam biçimidir. Bu dışarıda bırakılma hali, her şeyden önce bütünsel olarak toplumsal yapı içinde kendine yer bulamama ya da kendini ifade edememe halidir. Arzulanan yaşam biçimi ise öncelikle yaşamsal bir sorgulamayla ve arayışla ortaya çıkar Elbette bu arayış kişinin yaşamsal deneyimleri ile doğrudan ilişkilidir. Başka bir yaşamı deneyimlemiş olan birey, kendi yaşam dünyasını sorgulayabilmekte ve başka yaşamlarla bunu karşılaştırabilmektedir. Çalışma kapsamında yapılan görüşmeler göstermektedir ki, içinde yaşanılan dünyanın sorgulanması ve başka yaşamların arzulanması ile kişinin kültürel, sosyal deneyimleri ve eğitim seviyesi arasında doğrudan bir ilişki vardır. Toplum içindeki baskıları, mikro ve makro iktidar odakları, çevresel sorunları, toplumsal ilişkileri sorgulayabilme ve eleştirme, kişinin gündelik yaşamında doğrudan ya da dolaylı olarak karşılaştığ sorunlar karşısında arzuladığı bir yaşam biçiminin eksikliğini ortaya koyar ve bu eksiklik ise bir arayışa sevk eder. Öncelikle zihinsel olarak başlayan bu arayış her şeyden önce içinde yaşadığı topluma müdahaleye ve arzulanan eksikliğin giderilme çabasına dayanır. Ancak giderek daha otoriter olan yapı buna müsaade etmediğinde ise kişi yeni arayışlara, kaçış yollarına yönelir. Bu durum ise fiziksel olarak bir hareketliliği gerektirir.

Bu göç sürecine dâhil olan kişiler, geleneksel göç hareketliliği içindeki kişilerden ve bu beklentilerinden farklı bir duruşa sahiptir. Geleneksel göç hareketliliği içindeki insanlar içinde bulundukları yaşamsal koşulların zorluğundan (yoksulluk, imkânsızlık, savaş, doğal afet gibi) kaynaklı bir hareketlilik içindedirler. Hedef ülkede daha iyi bir yaşam kurma ve daha sonrasında geri dönme düşüncesi içindedirler. Fiziksel olarak göç ederler ama zihinsel olarak hala doğdukları, şimdiye kadar yaşadıkları coğrafyadadırlar. Bu çalışma kapsamında göç eden kişiler ise fiziksel olarak bir hareketliliğe girişmeden önce zihinsel olarak yaşadıkları coğrafyayı çoktan terk etmişlerdir. Fiziksel olarak terk etmek için ise uygun olan zamanı ve koşulları beklemektedirler. Bu durumu ise birçok görüşmeci "gemileri yakmak" tabiri ile ifade etmektedirler. Hayata dair beklentileri ve arzuları, kendi kendilerini yerinden etmektedir. $\mathrm{Bu}$ çalışmada bu durum "yerinden olma" ifadesi ile karşılık bulur.

Düşünce ve yaşam tarzı olarak tekil olan bireyin göç etme / gitme fikri ve motivasyonu, içinde bulunduğu gündelik hayattan ve baskıcı yapısından uzaklaşmayı ve başka yaşamların mümkün olduğu toplumları arzulamaya dayanır. Bu arayış sonucunda ortaya çıkan kaçış fikri, kendi gündelik yaşam mirası ve deneyimi içinde eksikliklere odaklanan bir yaşam tahayyülüne dayanır. Gündelik yaşam içinde eksik olanları arzulama düşüncesi, kişinin kendi yaşamsal deneyiminden doğan beklentileri içerir. Bu beklentiler ise kısaca mutluluk, huzur, güven, adil ve birlikte yaşamaya dayanan bir beklentiler çizgisini içerir. Temelde arzulanan bu duygular üzerine kurulu bir gündelik yaşam beklentisidir. Kişi, yaşadığı toplumda bu beklentilerine karşılık bulmadığında ve toplumsal alanda bunu gerçekleștirecek değişim sağlanamadığında boşluklar 
ortaya çıkar. Bunları iktidar odaklarını tehdit ve tedirgin eden boşluklardır. Ülke içinde yüksek eğitim almış, nitelikli meslek gruplarına ait olan kişilerin, gündelik hayata dair umutsuzlukları ve güvensizlikleri göçebe hale neden olmakta ve bu nitelikli işgücünün göç etmesi toplumsal alanda boşluklar yaratır. Bu boşluklar topluma, iktidar odaklarına, düzene karşı eleştirilerle dolu boşluklardır. Gerçek anlamda tüm dünyada değişimi sağlayacak şey, bu boşlukların eleştirilerle dolması ve bu eleştirilerin karşılık bulmasıdır.

En nihayetinde unutmamak gerekir ki, böylesine bir tekillik ve göçebe düşünce, sonsuz bir hareketliliği, arayışı içinde barındırır. Çünkü göçebe bir anlayış sürekli bir arayışı, özlemi, arzuyu içinde barındırır. Bir kere köklerinden kurtulmak, köksüz olmak hep yeni arayışları, sorgulamaları, arzuları doğuracaktır. Bir amok koşucusu gibi bu sonsuza kadar devam edecektir.

\section{Kaynakça}

Aksoy, A. (2007). Göçmenlik Deneyimine Kozmopolit Perspektiften Bakış. Kökler ve Yollar: Türkiye'de Göç Süreçleri, (ss. 421-444), İstanbul Bilgi Üniversitesi Yayınları.

Beck, U. (2002). The Cosmopolitian Perspective: Sociology in the Second Age of Modernty, Conceiving Cosmopolitanism: Theory, Context and Practice. (ss. 79-105) 0xford: Oxford University Press.

Braidotti, R. (2017). Göçebe Özneler, İstanbul: Kolektif Kitap

Çağlayan, S. (2006). Göç Kuramları, Göç ve Göçmen İlişkisi, Muğla Üniversitesi Sosyal Bilimler Dergisi, (17), 67-91.

Dahrendorf, R. (1958). Toward A Theory of Social Conflict. The Journal of Conflict Resolution, 2(2), 170-183.

Deleuze, G. (2002). Issız Ada ve Diğer Metinler: Metinler ve Söyleşiler 1953-1974. İstana bul: Bağlam Yayınları

Deleuze, G. \& Guattari, F. (1980). Mille Plateaux. Paris: Editions de Minuit.

Deleuze, G. \& Parnet, C. (1990) Diyaloglar. İstanbul: Bağlam Yayınları.

Demirtaș, M. (2017). Arzu Politikası: Deleuze ve Guattari Etkisi. İstanbul: Otonom Yayıncilık.

Diken, B. (2007), Göç: Eleştiri ve Politika Ötesi, Kökler ve Yollar: Türkiye’de Göç Süreçleri. (ss. 41-62). İstanbul: İstanbul Bilgi Üniversitesi Yayınları

Goodchild, P. (2005). Deleuze ve Guattari: Arzu Politikasına Giriş. İstanbul: Ayrıntı Ya: yınları

Lefebvre, H. (2013). Gündelik Hayatın Eleștirisi II: Gündelik Hayat Sosyolojisinin Temelleri. İstanbul: Sel Yayınları.

Lefebvre, H. (2014). Modern Dünyada Gündelik Hayat. İstanbul: Metis Yayınları.

Maffesoli, M. (2014). Göçebelik Üzerine: Ínisiyatik Başıboşluk. İstanbul: Bağlam YayınB ları.

Negri, A. \& Hardt, M. (2011). Ortak Zenginlik. Ayrıntı Yayınları: İstanbul

Özcan, E. (2017). Çağdaş Göç Teorileri Üzerine Bir Değerlendirme, İş ve Hayat, 2(4), 183-215. 
Said, E. (1990). Entellektüel: Sürgün, Marjinal, Yabancı. İstanbul: Ayrıntı Yayınları

Sirkeci, İ., \& Göktuna, F. (2019) Küresel Hareketlilik Çağında Göç Kuramları ve Temel Kavramlar. Kuramsal ve Uygulama Boyutları ile Türkiye'de Sığınmacı, Mülteci ve Göçmenlerle Sosyal Hizmetler (ss. 15-39). Londra: Transnational Press London

Stouffer, S.A. (1940). Intervening Opportunities: A Theory Relating Mobility and Distance, American Sociological Review, 5(6), 845-867.

Zourabichvili, F. (2011). Deleuze Sözlüğü. İstanbul: Say Yayınları. 
